Supporting Information

\title{
A Programmed Polymer Folding with \\ Periodically-Positioned Tetrafunctional Telechelic \\ Precursors by Cyclic Ammonium Salt Units as Nodal \\ Points
}

Kohei Kyoda, Takuya Yamamoto ${ }^{+}$, and Yasuyuki Tezuka*

Department of Organic and Polymeric Materials, Tokyo Institute of Technology, O-okayama,

Meguro-ku, Tokyo 152-8552, Japan

*Address corresponding to this author: ytezuka@o.cc.titech.ac.jp

${ }^{+}$Current Address; Division of Applied Chemistry, Faculty of Engineering, Hokkaido University,

Sapporo, Hokkaido, 060-8628, Japan. 


\section{Experimental Section}

\section{Materials}

$N$-phenylpyrrolidine was prepared according to the method reported previously. ${ }^{1}$ $N$-ethylpyrrolidine ( $>98 \%$, Tokyo Chemical Industry Co., Ltd.) was distilled over $\mathrm{CaH}_{2}$. $N$-(2-hydroxyethyl)pyrrolidine, (or 1-Pyrrolidineethanol or epolamine) ( $>98 \%$, Tokyo Chemical Industry Co., Ltd.) and propargyl bromide (>97\%, Tokyo Chemical Industry Co., Ltd.) were used as received. Sodium hydride (Nacalai Tesque) was used as received. THF (Kanto Chemical Co.,) was distilled over $\mathrm{Na}$ wire. Trifluoromethanesulfonic anhydride (triflic anhydride) (98\%, Nacalai Tesque, Inc.) was distilled from $\mathrm{P}_{2} \mathrm{O}_{5}$ just before use. 4-Azido benzoic acid ( $>97 \%$, Tokyo Chemical Industry Co., Ltd.), Phosphorus pentachloride (Sigma-Aldrich), Silver hexafluoroantimonate ( $>97 \%$, Tokyo Chemical Industry Co., Ltd.) 4,4'-Biphenyl dicarboxylate sodium salt was prepared according to the method reported previously. ${ }^{2}$ Toluene was used after distillation. $\mathrm{CuSO}_{4}-5 \mathrm{H}_{2} \mathrm{O}$ (Wako Chemical Co.,) and sodium ascorbate (Wako Chemical Co.,) were used as received. Other reagents were used as received otherwise noted. For flash chromatography, Wakosil C-300 (Wako Pure Chemical Industries, Ltd.) was used. 


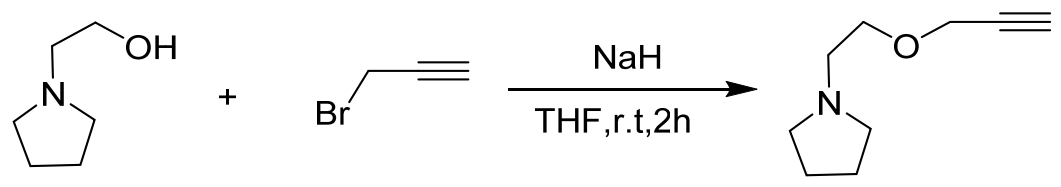

Into a $200 \mathrm{~mL}$ two-necked flask suspending $2.8 \mathrm{mg}(0.14 \mathrm{mmol}, 1.4 \mathrm{eq})$ of $\mathrm{NaH}$, obtained after washing with hexane three times, in anhydrous THF $(100 \mathrm{~mL})$, were added dropwise 11.75 $\mathrm{mL}(0.10 \mathrm{~mol}, 1.0 \mathrm{eq})$ of 1-pyrrolidine ethanol and $10.90 \mathrm{~mL}(0.10 \mathrm{~mol}, 1.0 \mathrm{eq})$ of propargyl bromide under nitrogen. After stirring for 2 hours, and the mixture was treated with methanol to deactivate $\mathrm{NaH}$, and the solvent was removed under reduced pressure. The product was then dissolved in toluene and washed with water 3 times and with brine once. After drying with sodium sulfate, toluene was removed under reduced pressure, and the product was purified through a silica gel column with acetone $/$ hexane $=1 / 2$ eluent, and dried with calcium hydride. The yield was $7.04 \mathrm{~g}(46 \%)$.

${ }^{1} \mathrm{H}$ NMR $\left(\mathrm{CDCl}_{3}\right)$ (Figure S1) $\delta(\mathrm{ppm}): 1.78\left(\mathrm{ddd}, 4 \mathrm{H}, \mathrm{NCH}_{2} \mathrm{CH}_{2}\right), 2.42\left(\mathrm{t}, 1 \mathrm{H}, \mathrm{CHCCH}_{2}\right), 2.55$ (t, $\left.4 \mathrm{H}, \mathrm{NCH}_{2} \mathrm{CH}_{2}\right) 2.70\left(\mathrm{t}, 2 \mathrm{H}, \mathrm{NCH}_{2} \mathrm{CH}_{2} \mathrm{O}\right), 3.67\left(\mathrm{t}, 2 \mathrm{H}, \mathrm{CH}_{2} \mathrm{OCH}_{2}\right), 4.18\left(\mathrm{~d}, 2 \mathrm{H}, \mathrm{OCH}_{2} \mathrm{CCH}\right)$

${ }^{13} \mathrm{C} \mathrm{NMR}\left(\mathrm{CDCl}_{3}\right)$ (Figure S2) $\delta(\mathrm{ppm}): 23.1,54.3,55.3,58.0,68.4,74.2,79.5$

Synthesis of a telechelic poly(THF) having $N$-propynyloxyethylpyrrolidinium groups (1)

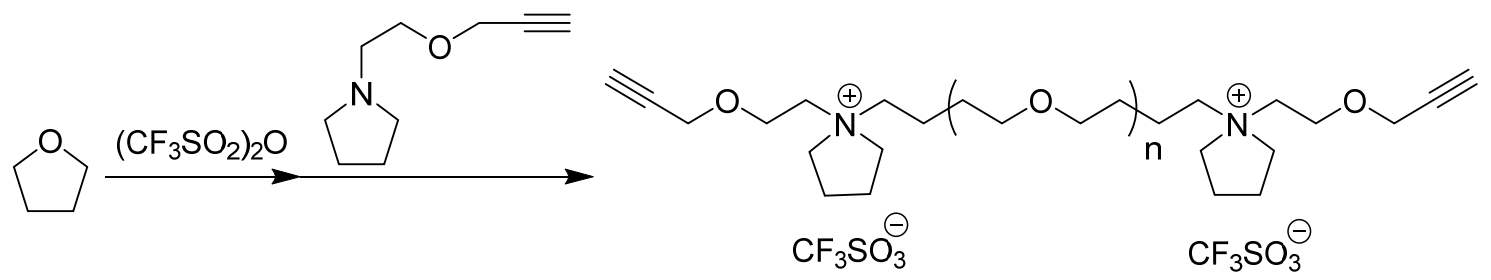


Into a $100 \mathrm{~mL}$ two-neck round bottom flask containing anhydrous THF $(50 \mathrm{~mL})$ thermostated at $25{ }^{\circ} \mathrm{C}$ added $0.10 \mathrm{~mL}(0.61 \mathrm{mmol}, 1 \mathrm{eq})$ of trifluoromethanesulfonic anhydride, obtained by Kugelrohr distillation, under nitrogen. The reaction was allowed to proceed under stirring for $7 \mathrm{~min}$, and the termination reagent, 1-(2-(2-propyn-1-yloxy)ethyl)pyrrolidine (0.96 $\mathrm{mL}(6.1 \mathrm{mmol}, 10 \mathrm{eq})$ was added. The reaction mixture was further stirred for $30 \mathrm{~min}$, and the solvent was removed under reduced pressure. The product was recovered by the reprecipitation three times into hexane cooled in a dry ice acetone bath, and was subjected to the vacuum drying. The yield was $1.67 \mathrm{~g}$. The molecular weight was $2800\left({ }^{1} \mathrm{H} \mathrm{NMR}\right)$.

${ }^{1} \mathrm{H}$ NMR $\left(\mathrm{CDCl}_{3}\right)$ (Figure 1/2, top), $\delta(\mathrm{ppm}): 1.57-1.71\left(\mathrm{~m}, \mathrm{CH}_{2} \mathrm{CH}_{2} \mathrm{O}\right), 1.73-1.93(\mathrm{~m}, 4 \mathrm{H}$, $\mathrm{NCH}_{2} \mathrm{CH}_{2}$ ), 2.08-2.24 (m, 4H, endo- $\left.\mathrm{NCH}_{2} \mathrm{CH}_{2}\right), 2.24-2.38\left(\mathrm{~m}, 4 \mathrm{H}\right.$, exo- $\left.\mathrm{NCH}_{2} \mathrm{CH}_{2}\right), 2.56(\mathrm{t}, 2 \mathrm{H}$, $\mathrm{CHCCH}_{2}$ ) 3.35-3.52 (m, $\left.\mathrm{CH}_{2} \mathrm{CH}_{2} \mathrm{O}\right), 3.59$ (t, 4H, $\left.\mathrm{CH}_{2} \mathrm{OCH}_{2}\right), 3.69$ (t, 4H, $\left.\mathrm{NCH}_{2} \mathrm{CH}_{2} \mathrm{O}\right)$, 3.72-3.83 (m, 4H, endo- $\left.\mathrm{NCH}_{2} \mathrm{CH}_{2}\right)$ ，3.90-4.01 (m, 4H，exo- $\left.\mathrm{NCH}_{2} \mathrm{CH}_{2}\right), 4.21(\mathrm{~d}, 4 \mathrm{H}$, $\left.\mathrm{OCH}_{2} \mathrm{CCH}\right)$

Covalent conversion product from 1

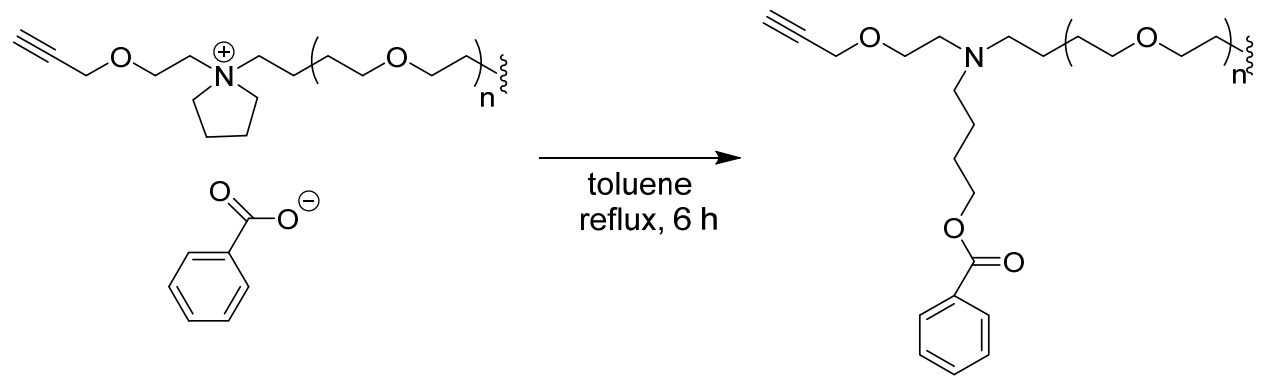


Into a $50 \mathrm{~mL}$ two-necked round-bottom flask introduced an acetone solution $(1.5 \mathrm{~mL})$ containing a telechelic poly(THF) having $\mathrm{N}$-propynyloxyethylpyrrolidinium groups (1). Thereupon $25 \mathrm{~mL}$ of distilled toluene, and $263 \mathrm{mg}(0.36 \mathrm{mmol})$ of tetrabutylammonium benzoate were added under nitrogen. The mixture was then heated under reflux for 6 hours, and the solvent was removed under reduced pressure. The product was subjected to the silica gel column chromatography with acetone, and finally isolated by the reprecipitation into water cooled with an ice bath. The yield was $77 \mathrm{mg}(77 \%)$.

${ }^{1} \mathrm{H}$ NMR $\left(\mathrm{CDCl}_{3}\right)$ (Figure S3), $\delta(\mathrm{ppm}): 1.57-1.71\left(\mathrm{~m}, \mathrm{CH}_{2} \mathrm{CH}_{2} \mathrm{O}\right), 1.73-1.93(\mathrm{~m}, 4 \mathrm{H}$, $\left.\mathrm{NCH}_{2} \mathrm{CH}_{2}\right), \quad 2.46\left(\mathrm{t}, 2 \mathrm{H}, \mathrm{CHCCH}_{2}\right), 2.75-2.99\left(\mathrm{~m}, 12 \mathrm{H}, \mathrm{NCH}_{2} \mathrm{CH}_{2}\right), 3.35-3.52\left(\mathrm{~m}, \mathrm{CH}_{2} \mathrm{CH}_{2} \mathrm{O}\right)$, $3.75\left(\mathrm{t}, 4 \mathrm{H}, \mathrm{CH}_{2} \mathrm{OCH}_{2}\right), 4.15\left(\mathrm{~d}, 4 \mathrm{H}, \mathrm{OCH}_{2} \mathrm{CCH}\right), 4.35\left(\mathrm{t}, 4 \mathrm{H}, \mathrm{COOCH}_{2}\right), 7.45$ (t, 4H, Ar- $H$ meta), 7.56 (t, 2H, Ar- $H$ para), 8.04 (d, 4H, Ar- $H$ ortho)

SEC (Figure 3, top) $: \mathrm{M}_{\mathrm{p}}=4400, \mathrm{PDI}=1.10$

MALDI-TOF mass (Figure S4): 3490.9 (obsd), 3490.07 (calcd with [M+H] $]^{+}$)

\section{Synthesis of a poly(THF) having an azidobenzoate and an $N$-ethylpyrrolidinium group}

(2a)

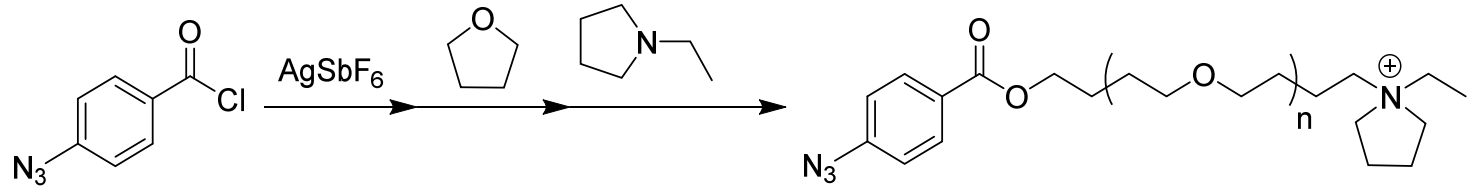


Into a $50 \mathrm{~mL}$ two-necked round-bottom flask containing $118.0 \mathrm{mg}(0.73 \mathrm{mmol}, 1 \mathrm{eq})$ of 4-azidobenzoic acid in $7 \mathrm{~mL}$ of anhydrous diethylether, added $168 \mathrm{mg}(0.80 \mathrm{mmol}, 1.1 \mathrm{eq})$ of $\mathrm{PCl}_{5}$. The reaction was allowed to proceed for $4 \mathrm{~h}$ by stirring under nitrogen at room temperature. After the vacuum drying treatment for $7 \mathrm{~h}$, a white solid product was obtained in the flask. Thereupon, $30 \mathrm{~mL}$ of anhydrous THF and $247 \mathrm{mg}(0.73 \mathrm{mmol})$ of $\mathrm{AgSbF}_{6}$ in $2.0 \mathrm{~mL}$ of THF were added under stirring at $0^{\circ} \mathrm{C}$. The mixture was stirred for $8 \mathrm{~min}$, and $1.1 \mathrm{~mL}(7.2$ mmol, 10 eq) of $N$-ethylpyrrolidine was added to stir for $2 \mathrm{~h}$ at $0^{\circ} \mathrm{C}$. The formed precipitate of $\mathrm{AgCl}$ was removed by filtration, and the product was recovered by the reprecipitation twice into hexane cooled by dry ice acetone bath. The yield was $1.16 \mathrm{~g}$. The molecular weight was $2500\left({ }^{1} \mathrm{H}-\mathrm{NMR}\right)$.

${ }^{1} \mathrm{H}$ NMR $\left(\mathrm{CDCl}_{3}\right)$ (Figure 1, middle), $\delta(\mathrm{ppm}): 1.38\left(\mathrm{t}, 3 \mathrm{H}, \mathrm{CH}_{3} \mathrm{CH}_{2} \mathrm{~N}\right), 1.57-1.71\left(\mathrm{~m}, \mathrm{CH}_{2} \mathrm{CH}_{2} \mathrm{O}\right)$, 1.73-1.93 (m, 2H, $\left.\mathrm{NCH}_{2} \mathrm{CH}_{2}\right)$ 2.10-2.19 (m, 2H, endo- $\left.\mathrm{NCH}_{2} \mathrm{CH}_{2}\right), 2.20-2.29(\mathrm{~m}, 2 \mathrm{H}$, exo- $\left.\mathrm{NCH}_{2} \mathrm{CH}_{2}\right), 3.21-3.31\left(\mathrm{~m}, 2 \mathrm{H}, \mathrm{CH}_{3} \mathrm{CH}_{2} \mathrm{~N}\right), 3.35-3.52\left(\mathrm{~m}, \mathrm{CH}_{2} \mathrm{CH}_{2} \mathrm{O}\right), 4.33(\mathrm{t}, 2 \mathrm{H}$, $\left.\mathrm{COOCH}_{2}\right), 7.06\left(\mathrm{~d}, 2 \mathrm{H}, \mathrm{Ar}-\mathrm{H}\right.$ ortho to $\left.\mathrm{N}_{3}\right), 8.03\left(\mathrm{~d}, 2 \mathrm{H}, \mathrm{Ar}-\mathrm{H}\right.$ meta to $\left.\mathrm{N}_{3}\right)$

Covalent conversion product from $\mathbf{2 a}$ 


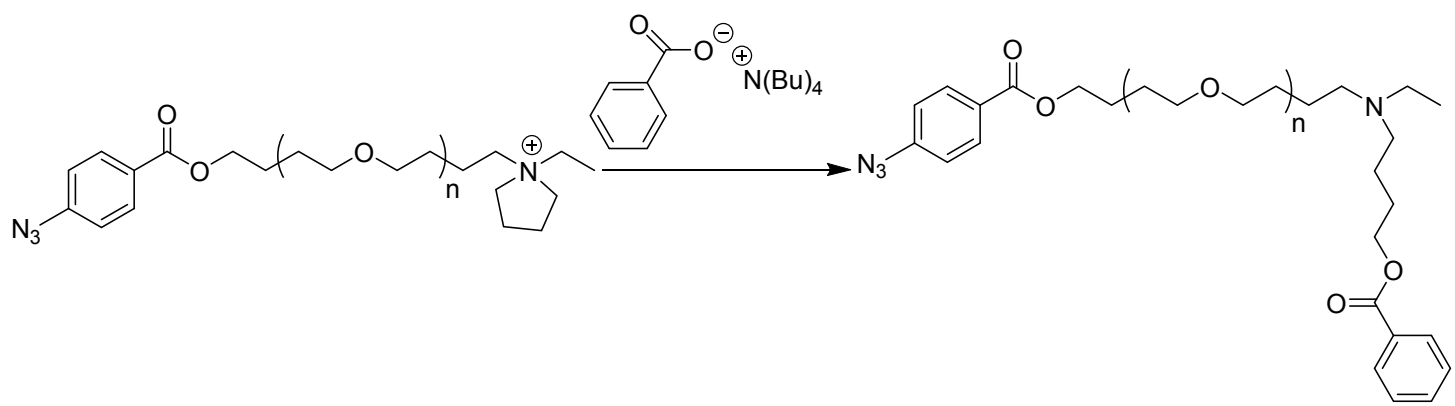

Into a $50 \mathrm{~mL}$ two-necked round-bottom flask containing $50 \mathrm{mg}(20 \mu \mathrm{mol}, 1 \mathrm{eq})$ of the poly(THF) having an $N$-ethylpyrrolidinium salt group in $25 \mathrm{~mL}$ of toluene, $75 \mathrm{mg}$ (20 mmol, 10 eq) of tetrabutylammonium benzoate was added under nitrogen. The mixture was heated to reflux and allowed to react for $6 \mathrm{~h}$ under stirring. The solvent was then removed under reduced pressure, and the product was purified twice by a silica gel column chromatography with acetone, and finally isolated by the reprecipitating into water cooled in an ice bath. The yield was $21 \mathrm{mg}(42 \%)$.

${ }^{1} \mathrm{H}$ NMR $\left(\mathrm{CDCl}_{3}\right)$ (Figure S5), $\delta(\mathrm{ppm}): 1.37\left(\mathrm{t}, 6 \mathrm{H}, \mathrm{CH}_{3} \mathrm{CH}_{2} \mathrm{~N}\right), 1.57-1.71\left(\mathrm{~m}, \mathrm{CH}_{2} \mathrm{CH}_{2} \mathrm{O}\right)$, 1.73-1.93 (m, 2H, $\left.\mathrm{NCH}_{2} \mathrm{CH}_{2}\right), 3.12\left(\mathrm{~m}, 2 \mathrm{H}, \mathrm{CH}_{3} \mathrm{CH}_{2} \mathrm{~N}\right), 3.35-3.52\left(\mathrm{~m}, \mathrm{CH}_{2} \mathrm{CH}_{2} \mathrm{O}\right), 4.34(\mathrm{t}, 4 \mathrm{H}$, $\left.\mathrm{COOCH}_{2}\right), 7.06\left(\mathrm{~d}, 2 \mathrm{H}, \mathrm{Ar}-H\right.$ ortho to $\left.\mathrm{N}_{3}\right), 7.43(\mathrm{t}, 2 \mathrm{H}, \mathrm{Ar}-H$ meta to $\mathrm{COO}), 7.56(\mathrm{t}, 1 \mathrm{H}, \mathrm{Ar}-H$ para to $\mathrm{COO}) 8.03$ (d, $4 \mathrm{H}, \mathrm{Ar}-H$ meta to $\mathrm{N}_{3}, \mathrm{Ar}-H$ ortho to $\mathrm{COO}$ )

SEC (Figure 3, middle, left) $: \mathrm{M}_{\mathrm{p}}=2900, \mathrm{PDI}=1.10$

MALDI-TOF mass (Figure S7): 2602.1 (obsd), 2601.75 (calcd with [M+H] $]^{+}$) 


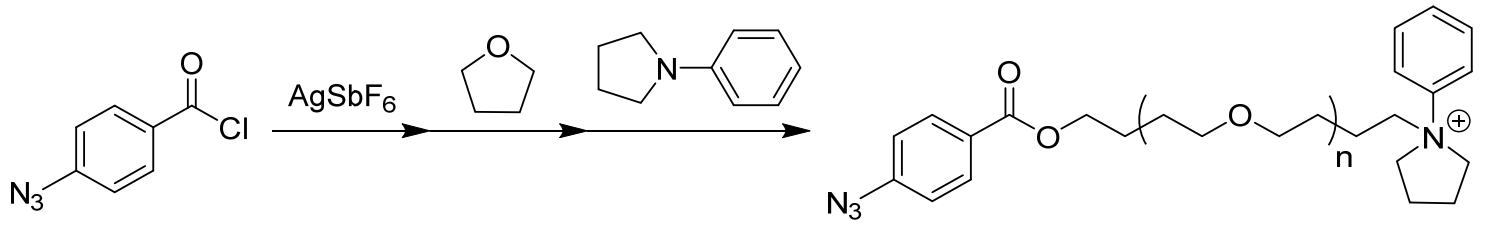

Into a $50 \mathrm{~mL}$ two-necked round-bottom flask containing $90.0 \mathrm{mg}(0.55 \mathrm{mmol}, 1 \mathrm{eq})$ of 4-azidobenzoic acid in $7 \mathrm{~mL}$ of anhydrous diethylether, added $126 \mathrm{mg}(0.60 \mathrm{mmol}, 1.1 \mathrm{eq})$ of $\mathrm{PCl}_{5}$. The reaction was allowed to proceed for $4 \mathrm{~h}$ by stirring under nitrogen at room temperature. After the vacuum drying treatment for 7 hours, a white solid product was obtained in the flask. Thereupon, $30 \mathrm{~mL}$ of anhydrous THF and $191 \mathrm{mg}(0.55 \mathrm{mmol})$ of $\mathrm{AgSbF}_{6}$ in $2.0 \mathrm{~mL}$ of THF were added under stirring at $0{ }^{\circ} \mathrm{C}$. The mixture was stirred for 8 min, and $0.82 \mathrm{~mL}$ (5.5 mmol, $10 \mathrm{eq})$ of $N$-ethylpyrrolidine was added to stir for $2 \mathrm{~h}$ at $0{ }^{\circ} \mathrm{C}$. The formed precipitate of $\mathrm{AgCl}$ was removed by filtration, and the product was recovered by the reprecipitation twice into hexane cooled by dry ice acetone bath. The yield was $1.16 \mathrm{~g}$. The molecular weight was 2500 (1 H-NMR).

${ }^{1} \mathrm{H}$ NMR $\left(\mathrm{CDCl}_{3}\right)$ (Figure 2, middle), $\delta(\mathrm{ppm}): 1.57-1.71\left(\mathrm{~m}, \mathrm{CH}_{2} \mathrm{CH}_{2} \mathrm{O}\right), 1.73-1.93(\mathrm{~m}, 2 \mathrm{H}$, $\mathrm{NCH}_{2} \mathrm{CH}_{2}$ ) 2.13-2.25 (m, 2H, endo- $\left.\mathrm{NCH}_{2} \mathrm{CH}_{2}\right), 2.33-2.48$ (m, $2 \mathrm{H}$, exo- $\left.\mathrm{NCH}_{2} \mathrm{CH}_{2}\right), 3.35-3.52$ (m, $\mathrm{CH}_{2} \mathrm{CH}_{2} \mathrm{O}$ ), 3.74 (t, 2H, $\mathrm{NCH}_{2} \mathrm{CH}_{2}$ ), 3.99-4.19 (m, 4H, endo-,exo- $\left.\mathrm{NCH}_{2} \mathrm{CH}_{2}\right), 4.33$ (t, 2H, $\left.\mathrm{COOCH}_{2}\right), 7.06\left(\mathrm{~d}, 2 \mathrm{H}, \mathrm{Ar}-H\right.$ ortho to $\left.\mathrm{N}_{3}\right), 7.51-7.68$ (m, 5H, Ar- $H$ ortho, meta, para to N), 8.03 $\left(\mathrm{d}, 2 \mathrm{H}, \mathrm{Ar}-\mathrm{H}\right.$ meta to $\left.\mathrm{N}_{3}\right)$ 
Covalent conversion product from $\mathbf{2 b}$

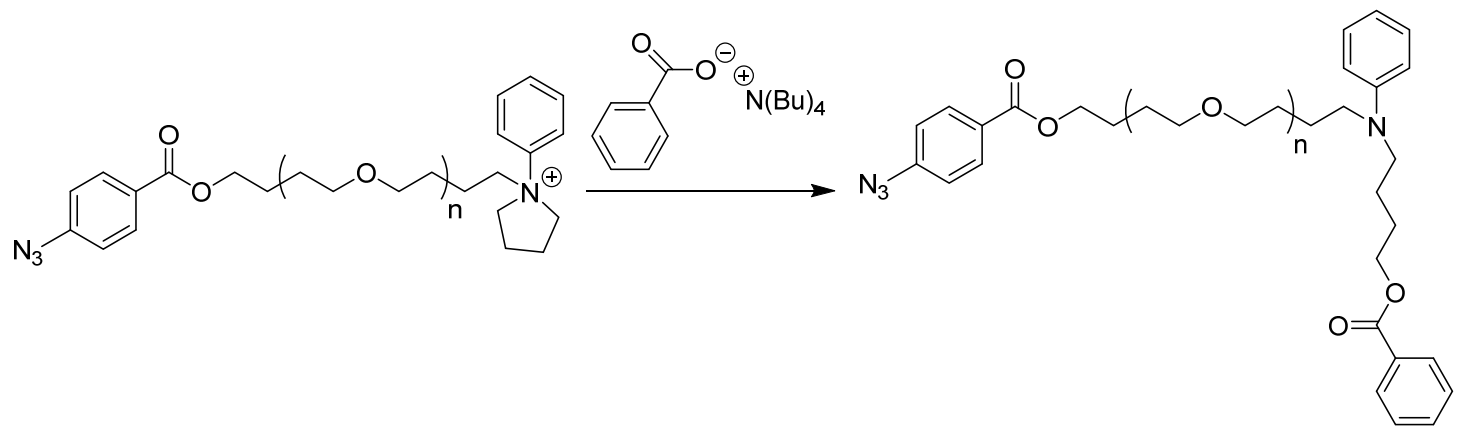

Into a $50 \mathrm{~mL}$ two-necked round-bottom flask containing $100 \mathrm{mg}(40 \mu \mathrm{mol}, 1 \mathrm{eq})$ of the poly(THF) having an $\mathrm{N}$-phenylpyrrolidinium salt group in $25 \mathrm{~mL}$ of chloroform, $146 \mathrm{mg}$ (40 mmol, 10 eq) of tetrabutylammonium benzoate was added under nitrogen. The mixture was heated to reflux and allowed to react for $3 \mathrm{~h}$ under stirring. The solvent was then removed under reduced pressure, and the product was purified twice by a silica gel column chromatography with acetone/hexane $(1 / 2 \mathrm{in} \mathrm{vol} / \mathrm{vol})$, and finally isolated by the reprecipitation three times into water cooled in an ice bath. The yield was $76 \mathrm{mg}(76 \%)$.

${ }^{1} \mathrm{H}$ NMR $\left(\mathrm{CDCl}_{3}\right)$ (Figure $\left.\mathrm{S} 6\right), \delta(\mathrm{ppm}): 1.57-1.71\left(\mathrm{~m}, \mathrm{CH}_{2} \mathrm{CH}_{2} \mathrm{O}\right), 1.73-1.93 \quad(\mathrm{~m}, 2 \mathrm{H}$, $\mathrm{NCH}_{2} \mathrm{CH}_{2}$ ), 3.35-3.52 (m, $\left.\mathrm{CH}_{2} \mathrm{CH}_{2} \mathrm{O}\right), 4.34$ (dd, 4H, $\left.\mathrm{COOCH}_{2}\right), 6.58-6.69$ (m, 3H, Ar- $H$ ortho, para to $\mathrm{N}) 7.06\left(\mathrm{~d}, 2 \mathrm{H}, \mathrm{Ar}-H\right.$ ortho to $\left.\mathrm{N}_{3}\right), 7.18(\mathrm{t}, 2 \mathrm{H}, \mathrm{Ar}-H$ meta to $\mathrm{N}), 7.43(\mathrm{t}, 2 \mathrm{H}$, Ar- $H$ meta to $\mathrm{COO}$ ), $7.56(\mathrm{t}, 1 \mathrm{H}, \mathrm{Ar}-H$ para to $\mathrm{COO}) 8.03$ (d, $4 \mathrm{H}, \mathrm{Ar}-H$ meta to $\mathrm{N}_{3}, \mathrm{Ar}-H$ ortho to COO)

SEC (Figure 3 (middle, right) : $\mathrm{M}_{\mathrm{p}}=3100, \mathrm{PDI}=1.10$

MALDI-TOF mass (Figure S8): 2674.0 (obsd), 2672.78 (calcd with [M+Na] ${ }^{+}$) 


\section{Synthesis of a periodically-positioned tetrafunctional poly(THF) having two}

\section{$\mathrm{N}$-ethylpyrrolidinium groups at the chain ends and two $\mathrm{N}$-dialkylpyrrolidinium groups at}

\section{the interior positions (Ia)}

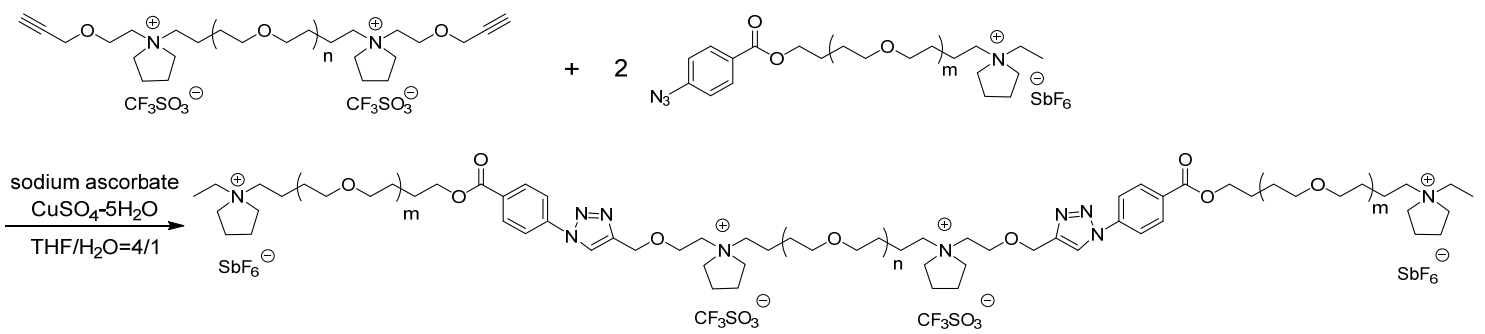

Into a $30 \mathrm{~mL}$ round-bottom flask placed $4 \mathrm{~mL}$ of anhydrous THF, $1 \mathrm{~mL}$ of deionized water, $68 \mathrm{mg}(25 \mu \mathrm{mol}, 1 \mathrm{eq})$ of the telechelic poly (THF) having an ethynyl and an $N$-dialkylpyrrolidinium group, 1 , and $138 \mathrm{mg}(55 \mu \mathrm{mol} 2.2 \mathrm{eq})$ of the telechelic poly (THF) having an azide and an $\mathrm{N}$-ethylpyrrolidinium group, 2a, were added under nitrogen. After the mixture was treated with the freeze-thaw three times, $149 \mathrm{mg}(0.75 \mathrm{mmol}, 30 \mathrm{eq})$ of sodium ascorbate and $94 \mathrm{mg}(0.38 \mathrm{mmol}, 15 \mathrm{eq})$ of copper sulfate pentahydrate were added to stir at room temperature for $90 \mathrm{~h}$. Thereafter, $15 \mathrm{~mL}$ of acetone was added to remove the precipitate by filtration, and the solvent was removed under reduced pressure. The resulted oily product was again dissolved in acetone, followed by the reprecipitation into water to isolate a periodically-positioned tetrafunctional poly(THF) having two $N$-ethylpyrrolidinium groups at the chain ends and two $N$-alkylpyrrolidinium groups at the interior positions (Ia). The yield was 
$198 \mathrm{mg}$.

${ }^{1} \mathrm{H}$ NMR $\left(\mathrm{CDCl}_{3}\right)$ (Figure 1, bottom), $\delta(\mathrm{ppm}): 1.37\left(\mathrm{t}, 6 \mathrm{H}, \mathrm{CH}_{3} \mathrm{CH}_{2} \mathrm{~N}\right)$ 1.57-1.71 (m, $\left.\mathrm{CH}_{2} \mathrm{CH}_{2} \mathrm{O}\right), 1.73-1.93\left(\mathrm{~m}, 8 \mathrm{H}, \mathrm{NCH}_{2} \mathrm{CH}_{2}\right), 2.02-2.37$ (m, $16 \mathrm{H}$, endo-, exo- $\left.\mathrm{NCH}_{2} \mathrm{CH}_{2}\right), 3.35-3.52$ $\left(\mathrm{m}, \mathrm{CH}_{2} \mathrm{CH}_{2} \mathrm{O}\right), 3.53-3.61\left(\mathrm{~m}, 4 \mathrm{H}, \mathrm{CH}_{2} \mathrm{OCH}_{2}\right), 3.92-4.12\left(\mathrm{~m}, 12 \mathrm{H}, \mathrm{NCH}_{2} \mathrm{CH}_{2} \mathrm{O}\right.$ endo-, exo- $\left.\mathrm{NCH}_{2} \mathrm{CH}_{2}\right), 4.28-4.41\left(\mathrm{~m}, 4 \mathrm{H}, \mathrm{COOCH}_{2}\right), 4.78\left(\mathrm{~s}, 4 \mathrm{H}, \mathrm{OCH}_{2}\right.$-triazole), 7.93 (d, 4H, Ar- $H$ ortho to triazole), $8.20(\mathrm{~d}, 4 \mathrm{H}, \mathrm{Ar}-H$ meta to triazole), 8.38 (s, $2 \mathrm{H}$, triazole- $H$ )

Covalent conversion product from Ia

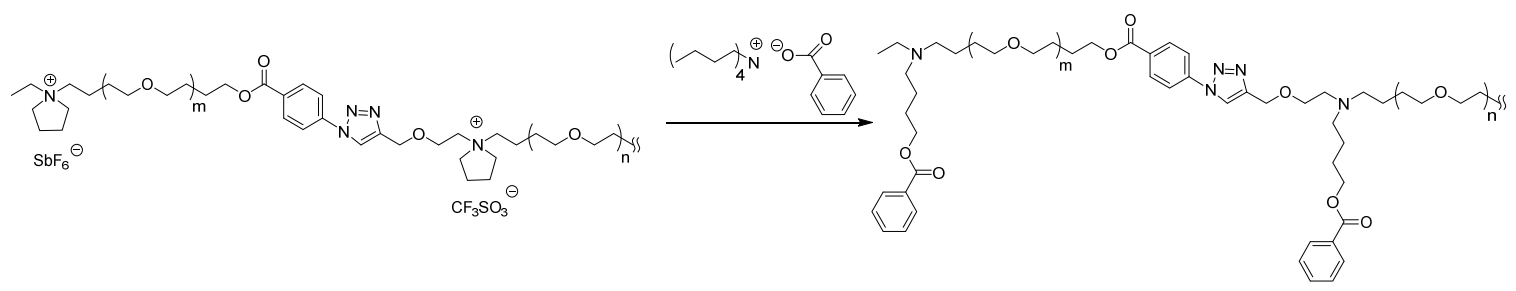

Into a $50 \mathrm{~mL}$ two-neck round-bottom flask containing $198 \mathrm{mg}$ of the tetrafunctional polymer precursor (Ia) in $25 \mathrm{~mL}$ of anhydrous toluene, $150 \mathrm{mg}(0.40 \mathrm{mmol}, 17 \mathrm{eq})$ of tetrabutylammonium benzoate was added to heat to reflux for $6 \mathrm{~h}$. The solvent was then removed under reduced pressure, and the product was treated by a silica gel column chromatography with acetone, and finally isolated by the reprecipitation three times into water cooled in an ice bath. The yield was $140 \mathrm{mg}(70 \%)$. Thereafter, the product was further purified by means of the preparative SEC technique.

${ }^{1} \mathrm{H}$ NMR $\left(\mathrm{CDCl}_{3}\right)$ (Figure S9), $\delta(\mathrm{ppm}): 1.37\left(\mathrm{t}, 6 \mathrm{H}, \mathrm{CH}_{3} \mathrm{CH}_{2} \mathrm{~N}\right), 1.57-1.71\left(\mathrm{~m}, \mathrm{CH}_{2} \mathrm{CH}_{2} \mathrm{O}\right)$, 
1.73-1.93 (m, 8H, $\left.\mathrm{NCH}_{2} \mathrm{CH}_{2}\right), 2.99-3.21\left(\mathrm{~m}, 4 \mathrm{H}, \mathrm{CH}_{3} \mathrm{CH}_{2} \mathrm{~N}\right), 3.35-3.52\left(\mathrm{~m}, \mathrm{CH}_{2} \mathrm{CH}_{2} \mathrm{O}\right)$, 4.01-4.20 (m, 4H, $\left.\mathrm{CH}_{2} \mathrm{OCH}_{2}\right), 4.25-4.42\left(\mathrm{~m}, 12 \mathrm{H}, \mathrm{COOCH}_{2}\right), 4.78\left(\mathrm{~s}, 4 \mathrm{H}, \mathrm{OCH}_{2}\right.$-triazole), 7.43 (t, $8 \mathrm{H}, \mathrm{Ar}-H$ meta to $\mathrm{COO}), 7.56$ (t, $4 \mathrm{H}, \mathrm{Ar}-H$ para to $\mathrm{COO}$ ), 7.91 (d, 4H, Ar- $H$ ortho to triazole), $8.02(\mathrm{t}, 8 \mathrm{H}, \mathrm{Ar}-H$ ortho to $\mathrm{COO}), 8.16(\mathrm{~d}, 4 \mathrm{H}, \mathrm{Ar}-H$ meta to triazole), $8.52(\mathrm{~s}, 2 \mathrm{H}$, triazole $-H)$ SEC (Figure 3 (bottom, left) : $M_{p}=9800,3000$ (before fractionation), $M_{p}=9700, P D I=1.09$ (after fractionation) MALDI-TOF mass (Figure 4, top): 7971.7 (obsd), 7972.50 (calcd with [M+H] $]^{+}$)

Ion-exchange reaction with biphenyl dicarboxylate

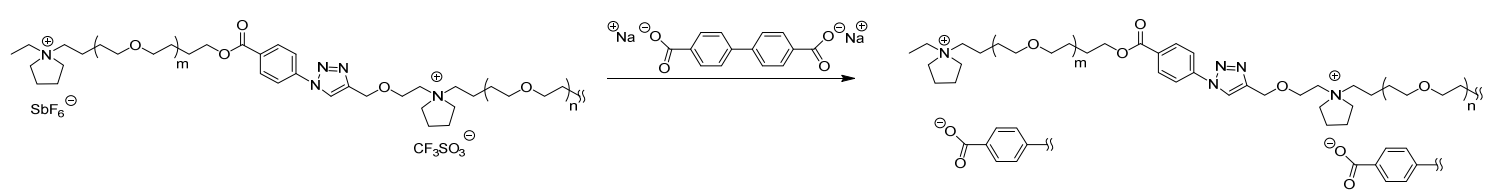

Into a $100 \mathrm{~mL}$ Erlenmeyer flask containing $150 \mathrm{mg}(0.53 \mathrm{mmol}, 22 \mathrm{eq})$ of sodium 4,4-biphenyldicarboxylate in $50 \mathrm{~mL}$ of deionized water, $201 \mathrm{mg}(23 \mu \mathrm{mol}, 1 \mathrm{eq})$ of the tetrafunctional linear telechelic precursor (Ia) dissolved in acetone was added dropwise to stir in an ice bath for $1 \mathrm{~h}$. The formed precipitate was collected by the suction filtration. The ion exchange procedure was repeated four times, and the ion-exchange product (Ia/dicarboxylate) was finally recovered by the vacuum drying. The yield was $140 \mathrm{mg}$, with the ion exchange yield of $56 \%\left({ }^{1} \mathrm{H}-\mathrm{NMR}\right)$. 
${ }^{1} \mathrm{H}$ NMR $\left(\mathrm{CDCl}_{3}\right)$ (Figure 5, top), $\delta(\mathrm{ppm}): 1.37\left(\mathrm{~m}, 6 \mathrm{H}, \mathrm{CH}_{3} \mathrm{CH}_{2} \mathrm{~N}\right)$ 1.57-1.71 (m, $\left.\mathrm{CH}_{2} \mathrm{CH}_{2} \mathrm{O}\right)$, 1.73-1.93 (m, 8H, $\left.\mathrm{NCH}_{2} \mathrm{CH}_{2}\right), 1.95-2.37\left(\mathrm{~m}, 16 \mathrm{H}\right.$, endo-, exo- $\left.\mathrm{NCH}_{2} \mathrm{CH}_{2}\right), 3.35-3.52(\mathrm{~m}$, $\left.\mathrm{CH}_{2} \mathrm{CH}_{2} \mathrm{O}\right), \quad 3.53-3.61\left(\mathrm{~m}, 4 \mathrm{H}, \quad \mathrm{CH}_{2} \mathrm{OCH}_{2}\right), 3.92-4.12\left(\mathrm{~m}, 12 \mathrm{H}, \quad \mathrm{NCH}_{2} \mathrm{CH}_{2} \mathrm{O}\right.$ endo-, exo- $\left.\mathrm{NCH}_{2} \mathrm{CH}_{2}\right), 4.28-4.41\left(\mathrm{~m}, 4 \mathrm{H}, \mathrm{COOCH}_{2}\right), 4.78\left(\mathrm{~s}, 4 \mathrm{H}, \mathrm{OCH}_{2}\right.$-triazole), 7.45-7.62 (m, 8H, Ar- $H$ meta to COO), 7.93 (d, $4 \mathrm{H}$, Ar- $H$ ortho to triazole), 7.94-8.20 (m, $12 \mathrm{H}$, Ar- $H$ ortho to $\mathrm{COO}, \mathrm{Ar}-H$ meta to triazole), 8.47 (s, $2 \mathrm{H}$, triazole- $H$ )

Polymer folding reaction of $\mathbf{I a} /$ dicarboxylate

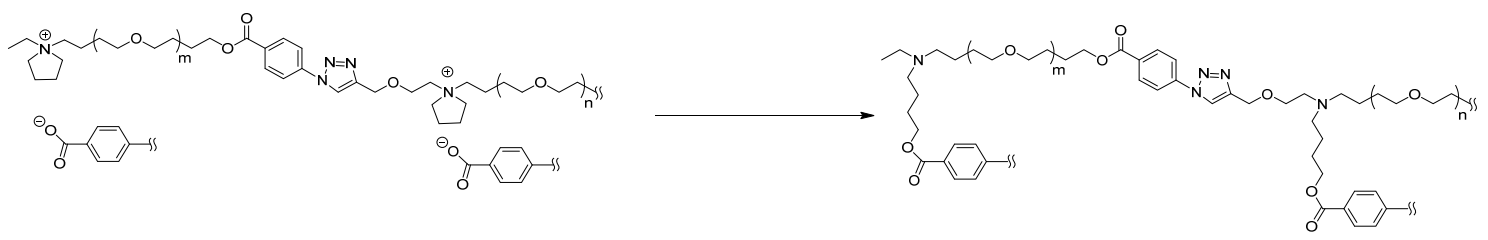

Into a $1 \mathrm{~L}$ two-necked round-bottom flask placed $120 \mathrm{mg}$ of the ion-exchanged tetrafunctional telechelic precursor (Ia/dicarboxylate) in $600 \mathrm{~mL}$ toluene. The solution was heated to reflux for $6 \mathrm{~h}$ under nitrogen. The solvent was then removed under reduced pressure, and the product was treated by the silica gel column chromatography with acetone, and finally recovered by the reprecipitation into water cooled with an ice bath. The yield of IIa was 72 $\mathrm{mg}(60 \%)$. Thereafter, the product was further purified by means of the preparative SEC technique.

${ }^{1} \mathrm{H}$ NMR $\left(\mathrm{CDCl}_{3}\right)$ (Figure 5, bottom), $\delta(\mathrm{ppm}): 1.37\left(\mathrm{t}, 6 \mathrm{H}, \mathrm{CH}_{3} \mathrm{CH}_{2} \mathrm{~N}\right), 1.57-1.71(\mathrm{~m}$, 
$\left.\mathrm{CH}_{2} \mathrm{CH}_{2} \mathrm{O}\right), 1.73-1.93\left(\mathrm{~m}, 8 \mathrm{H}, \mathrm{NCH}_{2} \mathrm{CH}_{2}\right), 2.99-3.21\left(\mathrm{~m}, 4 \mathrm{H}, \mathrm{CH}_{3} \mathrm{CH}_{2} \mathrm{~N}\right), 3.35-3.52(\mathrm{~m}$, $\left.\mathrm{CH}_{2} \mathrm{CH}_{2} \mathrm{O}\right), 4.01-4.20\left(\mathrm{~m}, 4 \mathrm{H}, \mathrm{CH}_{2} \mathrm{OCH}_{2}\right), 4.25-4.42\left(\mathrm{~m}, 12 \mathrm{H}, \mathrm{COOCH}_{2}\right), 4.78(\mathrm{~s}, 4 \mathrm{H}$, $\mathrm{OCH}_{2}$-triazole), 7.68 (d, $8 \mathrm{H}, \mathrm{Ar}-\mathrm{H}$ meta to $\mathrm{COO}$ ), 7.87 (d, $4 \mathrm{H}, \mathrm{Ar}-H$ ortho to triazole), 8.08 (d, $8 \mathrm{H}, \mathrm{Ar}-H$ ortho to $\mathrm{COO}), 8.17$ (d, $4 \mathrm{H}, \mathrm{Ar}-H$ meta to triazole), 8.37 (s, $2 \mathrm{H}$, triazole- $H$ ) SEC (Figure 7, bottom, left): $\mathrm{M}_{\mathrm{p}}=7900,2900$ (before fractionation), $\mathrm{M}_{\mathrm{p}}=8200, \mathrm{PDI}=1.06$ (after fractionation) MALDI-TOF mass (Figure 8, top): 7994.5 (obsd), 7992.56 (calcd with [M+Na] $]^{+}$)

\section{Synthesis of a periodically-positioned tetrafunctional poly(THF) having two}

\section{$\mathrm{N}$-phenylpyrrolidinium groups at the chain ends and two $\mathrm{N}$-dialkylpyrrolidinium groups}

at the interior positions (Ib)
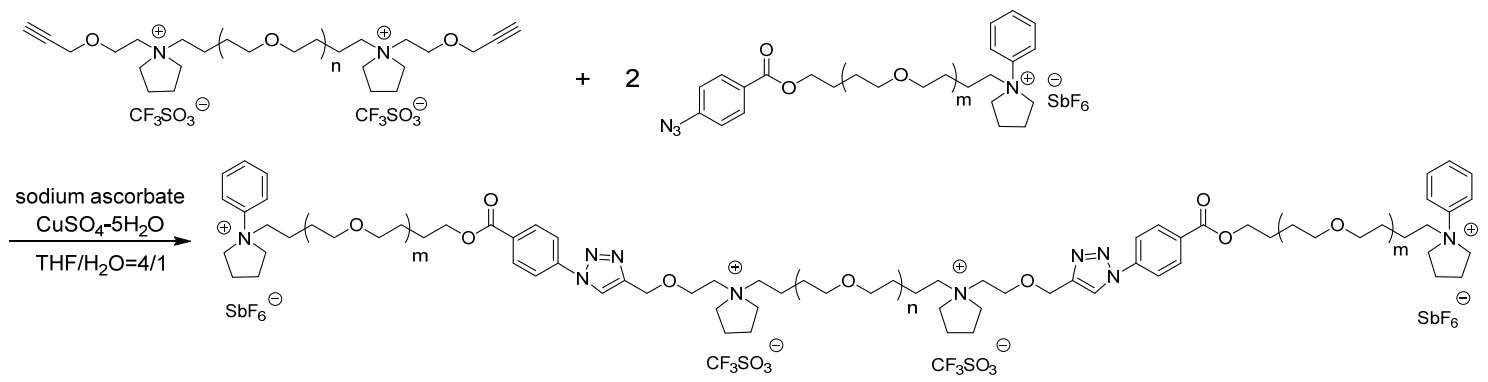

Into a $30 \mathrm{~mL}$ round-bottom flask placed $4 \mathrm{~mL}$ of anhydrous THF, $1 \mathrm{~mL}$ of deionized water, $70 \mathrm{mg}(25 \mu \mathrm{mol}, 1 \mathrm{eq})$ of the telechelic poly (THF) having an ethynyl and an $N$-dialkylpyrrolidinium group, $\mathbf{1}$, and $154 \mathrm{mg}(55 \mu \mathrm{mol} 2.2 \mathrm{eq})$ of the telechelic poly (THF) having an azide and an $N$-phenylpyrrolidinium group, $\mathbf{2} \mathbf{b}$, were added under nitrogen. After 
the mixture was treated with the freeze-thaw three times, $148 \mathrm{mg}(0.75 \mathrm{mmol}, 30 \mathrm{eq})$ of sodium ascorbate and $94 \mathrm{mg}(0.38 \mathrm{mmol}, 15 \mathrm{eq})$ of copper sulfate pentahydrate were added to stir at room temperature for $24 \mathrm{~h}$. Thereafter, $15 \mathrm{~mL}$ of acetone was added to remove the precipitate by filtration, and the solvent was removed under reduced pressure. The resulted oily product was again dissolved in acetone, followed by the reprecipitation into water to isolate a periodically-positioned tetrafunctional poly(THF) having two $N$-phenylpyrrolidinium groups at the chain ends and two $\mathrm{N}$-alkylpyrrolidinium groups at the interior positions (Ib). The yield was $200 \mathrm{mg}$.

${ }^{1} \mathrm{H}$ NMR $\left(\mathrm{CDCl}_{3}\right)$ (Figure 2, bottom), $\delta(\mathrm{ppm}): 1.57-1.71\left(\mathrm{~m}, \mathrm{CH}_{2} \mathrm{CH}_{2} \mathrm{O}\right), 1.73-1.93(\mathrm{~m}, 8 \mathrm{H}$, $\left.\mathrm{NCH}_{2} \mathrm{CH}_{2}\right), 2.08-2.32\left(\mathrm{~m}, 8 \mathrm{H}\right.$, endo- $\left.\mathrm{NCH}_{2} \mathrm{CH}_{2}\right), 2.32-2.48\left(\mathrm{~m}, 8 \mathrm{H}\right.$, exo- $\left.\mathrm{NCH}_{2} \mathrm{CH}_{2}\right), 3.35-3.52$ (m, $\mathrm{CH}_{2} \mathrm{CH}_{2} \mathrm{O}$ ), 3.53-3.61 (m, 4H, $\left.\mathrm{CH}_{2} \mathrm{OCH}_{2}\right), 3.75-3.85\left(\mathrm{~m}, 4 \mathrm{H}, \mathrm{PhNCH}_{2}\right), 3.92-4.12(\mathrm{~m}, 12 \mathrm{H}$, $\mathrm{NCH}_{2} \mathrm{CH}_{2} \mathrm{O}$ endo-, exo- $\mathrm{NCH}_{2} \mathrm{CH}_{2}$ ), 4.12-4.27 (m, 8H, endo-, exo- $\left.\mathrm{PhNCH}_{2} \mathrm{CH}_{2}\right), 4.28-4.41$ (m, $\left.4 \mathrm{H}, \mathrm{COOCH}_{2}\right), 4.78\left(\mathrm{~s}, 4 \mathrm{H}, \mathrm{OCH}_{2}\right.$-triazole), 7.51-7.66 (m, $10 \mathrm{H}, \mathrm{Ar}-\mathrm{H}$ ortho, meta, para to $\left.\mathrm{N}\right)$, $7.93(\mathrm{~d}, 4 \mathrm{H}, \mathrm{Ar}-H$ ortho to triazole), 8.20 (d, 4H, Ar- $H$ meta to triazole), 8.40 (s, $2 \mathrm{H}$, triazole- $H$ )

Covalent conversion product from Ib

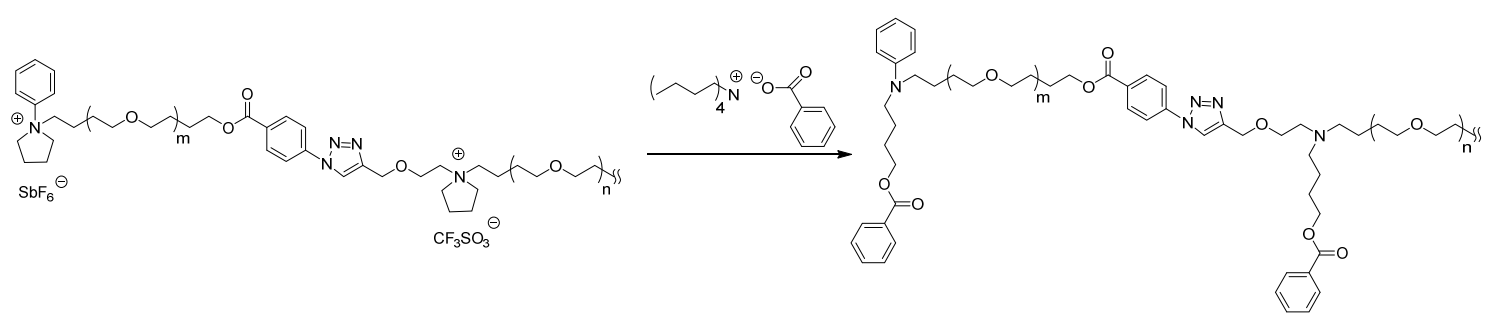


Into a $50 \mathrm{~mL}$ two-necked round-bottom flask containing $190 \mathrm{mg}$ of the tetrafunctional polymer precursor (Ib) in $25 \mathrm{~mL}$ of anhydrous toluene, $150 \mathrm{mg}(0.40 \mathrm{mmol}, 17 \mathrm{eq})$ of tetrabutylammonium benzoate was added to heat to reflux for $6 \mathrm{~h}$. The solvent was then removed under reduced pressure, and the product was treated by a silica gel column chromatography with acetone, and finally isolated by the reprecipitation three times into water cooled in an ice bath. The yield was $112 \mathrm{mg}(59 \%)$. Thereafter, the product was further purified by means of the preparative SEC technique.

${ }^{1} \mathrm{H}$ NMR $\left(\mathrm{CDCl}_{3}\right)$ (Figure S10), $\delta(\mathrm{ppm}): 1.57-1.71\left(\mathrm{~m}, \mathrm{CH}_{2} \mathrm{CH}_{2} \mathrm{O}\right), 1.73-1.93(\mathrm{~m}, 8 \mathrm{H}$, $\left.\mathrm{NCH}_{2} \mathrm{CH}_{2}\right), 3.35-3.52\left(\mathrm{~m}, \mathrm{CH}_{2} \mathrm{CH}_{2} \mathrm{O}\right), 4.01-4.20\left(\mathrm{~m}, 4 \mathrm{H}, \mathrm{CH}_{2} \mathrm{OCH}_{2}\right), 4.25-4.42(\mathrm{~m}, 12 \mathrm{H}$, $\left.\mathrm{COOCH}_{2}\right), 4.78$ (s, 4H, OCH$H_{2}$-triazole), 6.58- 6.69 (m, 6H, Ar- $H$ ortho, para to N), 7.18 (t, $4 \mathrm{H}$, Ar- $H$ meta to N), 7.43 (t, $8 \mathrm{H}, \mathrm{Ar}-H$ meta to $\mathrm{COO}), 7.56$ (t, 8H, Ar- $H$ para to COO), $7.91(\mathrm{~d}, 4 \mathrm{H}$, Ar- $H$ ortho to triazole), 8.02 (t, $8 \mathrm{H}, \mathrm{Ar}-H$ ortho to $\mathrm{COO}$ ), 8.16 (d, $4 \mathrm{H}, \mathrm{Ar}-H$ meta to triazole), $8.52(\mathrm{~s}, 2 \mathrm{H}$, triazole- $H)$

SEC (Figure 3 (bottom, right) : $M_{p}=9500,3100$ (before fractionation), $M_{p}=9500, P D I=1.05$ (after fractionation) :

MALDI-TOF mass (Figure 4, bottom): 8089.1 (obsd), 8090.58 (calcd with [M+Na] $]^{+}$)

Ion-exchange reaction of $\mathbf{I b}$ with biphenyl dicarboxylate 


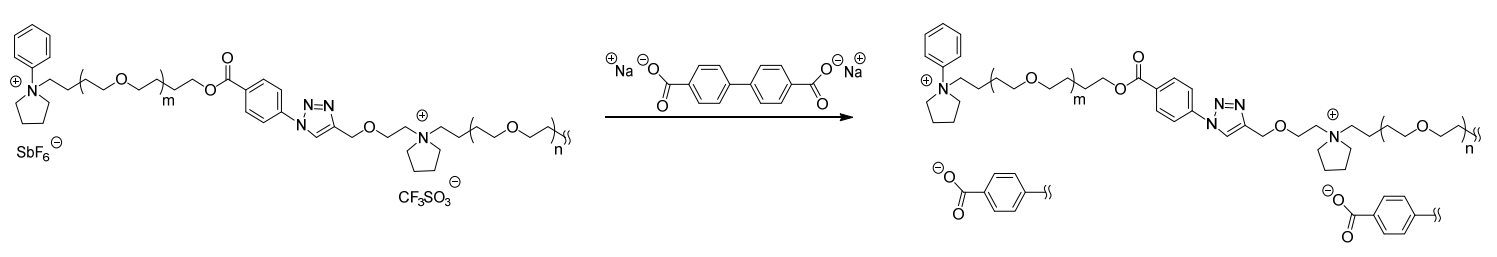

Into a $100 \mathrm{~mL}$ Erlenmeyer flask containing $152 \mathrm{mg}(0.53 \mathrm{mmol}, 26 \mathrm{eq})$ of sodium 4,4-biphenyldicarboxylate in $50 \mathrm{~mL}$ of deionized water, $172 \mathrm{mg}(20 \mu \mathrm{mol}, 1 \mathrm{eq})$ of the tetrafunctional linear telechelic precursor (Ib) dissolved in acetone was added dropwise to stir in an ice bath for $1 \mathrm{~h}$. The formed precipitate was collected by the suction filtration. The ion exchange procedure was repeated four times, and the ion-exchange product (Ib/dicarboxylate) was finally recovered by the vacuum drying. The yield was $120 \mathrm{mg}$, with the ion exchange yield of $70 \%\left({ }^{1} \mathrm{H}-\mathrm{NMR}\right)$.

${ }^{1} \mathrm{H}$ NMR $\left(\mathrm{CDCl}_{3}\right)$ (Figure 6, top), $\delta(\mathrm{ppm}): 1.57-1.71\left(\mathrm{~m}, \mathrm{CH}_{2} \mathrm{CH}_{2} \mathrm{O}\right), 1.73-1.93(\mathrm{~m}, 8 \mathrm{H}$, $\left.\mathrm{NCH}_{2} \mathrm{CH}_{2}\right), 2.08-2.32\left(\mathrm{~m}, 8 \mathrm{H}\right.$, endo- $\left.\mathrm{NCH}_{2} \mathrm{CH}_{2}\right), 2.32-2.48$ (m, 8H, exo- $\left.\mathrm{NCH}_{2} \mathrm{CH}_{2}\right), 3.35-3.52$ (m, $\mathrm{CH}_{2} \mathrm{CH}_{2} \mathrm{O}$ ), 3.60-3.68 (m, 4H, $\left.\mathrm{CH}_{2} \mathrm{OCH}_{2}\right), 3.69-3.84\left(\mathrm{~m}, 4 \mathrm{H}, \mathrm{PhNCH}_{2}\right), 3.92-4.12(\mathrm{~m}, 20 \mathrm{H}$, $\mathrm{NCH}_{2} \mathrm{CH}_{2} \mathrm{O}$ endo-, exo- $\mathrm{NCH}_{2} \mathrm{CH}_{2}$, endo-, exo- $\left.\mathrm{PhNCH}_{2} \mathrm{CH}_{2}\right), 4.28-4.47$ (m, 4H, $\left.\mathrm{COOCH}_{2}\right), 4.75$ (s, 4H, $\mathrm{OCH}_{2}$-triazole), 7.48-7.69 (m, $18 \mathrm{H}, \mathrm{Ar}-\mathrm{H}$ ortho, meta, para to N, Ar- $H$ meta to $\mathrm{COO}$ ), $7.91(\mathrm{~d}, 4 \mathrm{H}, \mathrm{Ar}-H$ ortho to triazole), 8.11 (d, $8 \mathrm{H}, \mathrm{Ar}-H$ ortho to $\mathrm{COO}), 8.19$ (d, $4 \mathrm{H}, \mathrm{Ar}-H$ meta to triazole), $8.46(\mathrm{~s}, 2 \mathrm{H}$, triazole- $H)$

Polymr folding reaction of $\mathbf{I b} /$ dicarboxylate 

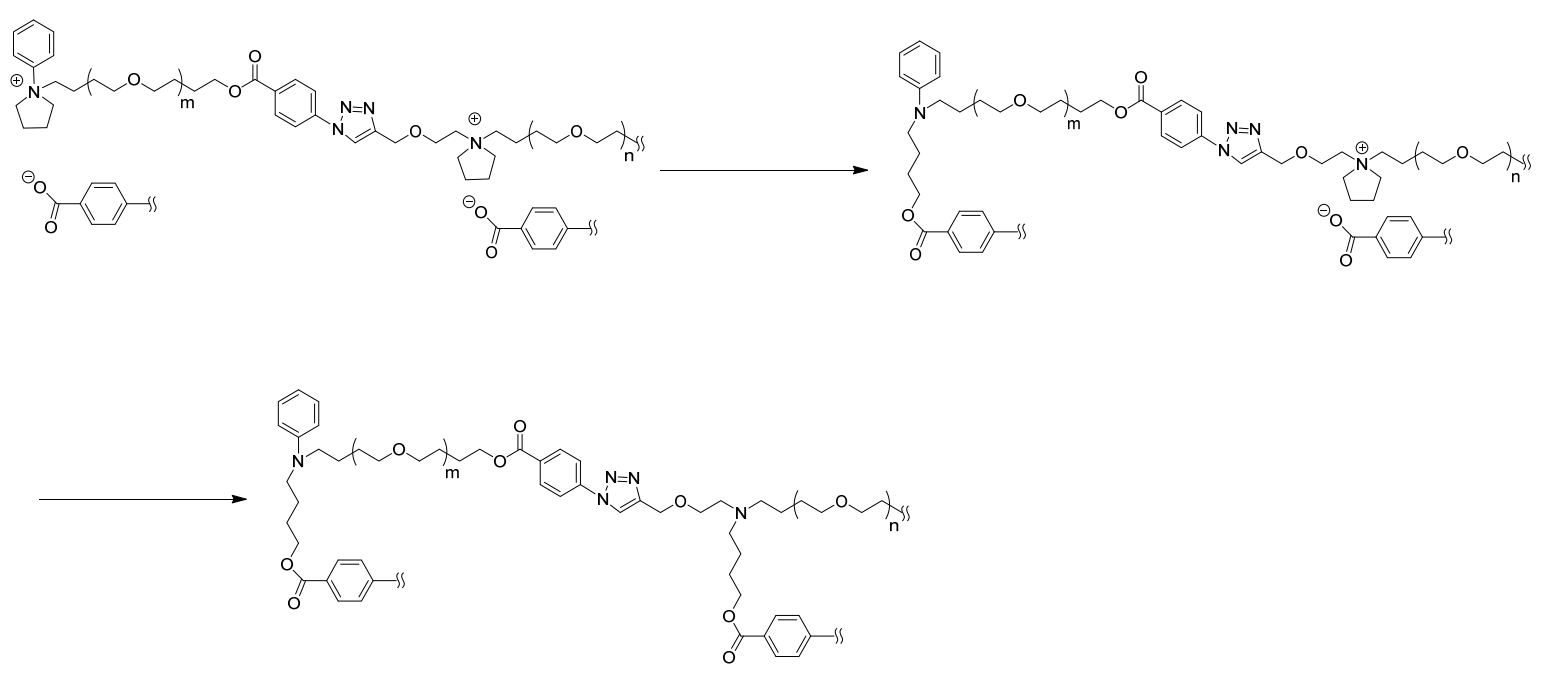

Into a $1 \mathrm{~L}$ two-necked round-bottom flask placed $120 \mathrm{mg}$ of the ion-exchanged tetrafunctional telechelic precursor (Ib/dicarboxylate) in $600 \mathrm{~mL}$ toluene. The solution was heated to $70{ }^{\circ} \mathrm{C}$ for $3 \mathrm{~h}$, to sampling out $60 \mathrm{~mL}$ of the mixture for the ${ }^{1} \mathrm{H}$ NMR monitoring, and the residual solution was allowed to proceed the reaction by heating up to $110{ }^{\circ} \mathrm{C}$ for $6 \mathrm{~h}$ under nitrogen. The solvent was then removed under reduced pressure, and the product was treated by the silica gel column chromatography with acetone, and finally recovered by the reprecipitation into water cooled with an ice bath. The yield was $62 \mathrm{mg}(62 \%)$. Thereafter, the product was further purified by means of the preparative SEC technique.

${ }^{1} \mathrm{H}$ NMR $\left(\mathrm{CDCl}_{3}\right)$ (Figure 6, bottom), $\delta(\mathrm{ppm}): 1.57-1.71\left(\mathrm{~m}, \mathrm{CH}_{2} \mathrm{CH}_{2} \mathrm{O}\right), 1.73-1.93(\mathrm{~m}, 8 \mathrm{H}$, $\left.\mathrm{NCH}_{2} \mathrm{CH}_{2}\right), 3.35-3.52\left(\mathrm{~m}, \mathrm{CH}_{2} \mathrm{CH}_{2} \mathrm{O}\right), 4.01-4.20\left(\mathrm{~m}, 4 \mathrm{H}, \mathrm{CH}_{2} \mathrm{OCH}_{2}\right), 4.25-4.42(\mathrm{~m}, 12 \mathrm{H}$, $\left.\mathrm{COOCH}_{2}\right), 4.78\left(\mathrm{~s}, 4 \mathrm{H}, \mathrm{OCH}_{2}\right.$-triazole), 6.58- 6.69 (m, 6H, Ar- $H$ ortho, para to $\left.\mathrm{N}\right), 7.18(\mathrm{t}, 4 \mathrm{H}$, Ar- $H$ meta to N), 7.68 (d, $8 \mathrm{H}, \mathrm{Ar}-H$ meta to $\mathrm{COO}$ ), 8.01 (d, 4H, Ar- $H$ ortho to triazole), 8.09 (d, 
$8 \mathrm{H}, \mathrm{Ar}-H$ ortho to $\mathrm{COO}), 8.21$ (d, $4 \mathrm{H}, \mathrm{Ar}-H$ meta to triazole), 8.52 (s, $2 \mathrm{H}$, triazole- $H$ )

SEC (Figure 7 (bottom, right) : $\mathrm{M}_{\mathrm{p}}=7300,3200$ (before fractionation), $\mathrm{M}_{\mathrm{p}}=7400, \mathrm{PDI}=1.06$

(after fractionation)

MALDI-TOF mass (Figure 8, bottom): 8084.7 (obsd), 8086.32 (calcd with [M+Na] $]^{+}$)

\section{Measurements}

${ }^{1} \mathrm{H}$ NMR spectra were recorded on a JEOL JNM-AL300 apparatus using $\mathrm{CDCl}_{3}$ as a solvent, with the chemical shifts ( $\mathrm{ppm})$ referenced to the signal of tetramethylsilane. Size exclusion chromatography (SEC) measurements were performed using a Tosoh model CCPS equipped with a refractive index detector model RI 8020 and a UV detector model UV 8020 at $254 \mathrm{~nm}$, and with a column of TSK G3000HXL with THF with trimethylamine $(7 \mathrm{~mL}$ in $1 \mathrm{~L}$ THF) as an eluent at a flow rate of $1.0 \mathrm{~mL} / \mathrm{min}$ at $40{ }^{\circ} \mathrm{C}$. The molecular weights were estimated by the calibration of polystyrene standard samples with the conversion factor of 0.556 for poly(THF)s. ${ }^{3} \quad$ MALDI-TOF mass spectra were recorded on a Shimadzu AXIMA-performance mass spectrometer equipped with a nitrogen laser $(\lambda=337 \mathrm{~nm})$ and pulsed ion extraction. The spectrometer was operated at an accelerating potential of $20 \mathrm{kV}$ with a linear-positive ion mode. THF solutions of a polymer sample $(1 \mathrm{~g} / \mathrm{L})$, dithranol $(10 \mathrm{~g} / \mathrm{L})$ and sodium trifluoroacetate $(1 \mathrm{~g} / \mathrm{L})$ were mixed $(25 / 50 / 25$ in $\mu \mathrm{L} / \mu \mathrm{L} / \mu \mathrm{L})$, and a $1 \mu \mathrm{L}$ portion of the 
mixture was deposited onto a sample target plate. Mass values were calibrated by the four-point method using SpheriCal ${ }^{\mathrm{TM}}$ dendrimeric calibrants (Polymer Factory, Sweden), at 3636.44 Da, 4816.89 Da, 5997.34 Da and 7263.87 Da (dendrimer plus $\mathrm{Na}^{+}$).

\section{References}

1. Oike, H.; Imamura, H.; Imaizumi, H.; Tezuka, Y., Tailored Synthesis of Branched and Network Polymer Structures by Electrostatic Self-Assembly and covalent Fixation with Telechelic Poly(THF) Having N-Phenylpyrrolidinium Salt Groups, Macromolecules, 1999, 32, 4819-4825.

2. Oike, H.; Imaizumi, H.; Mouri, T.; Yoshioka, Y.; Uchibori, A.; Tezuka, Y., Designing Unusual Polymer Topologies by Electrostatic Self-Assembly and Covalent Fixation, J. Am. Chem. Soc., 2000, 122, 9592-9599.

3. Burgess, F. J.; Cunliffe, A. V.; Dawkins, J. V.; Richards, D. H., Reaction to effect the transformation of anionic polymerization into cationic polymerization: 3 . Analysis of block copolymer formation by gel permeation chromatography, Polymer, 1977, 18, 733-740. 


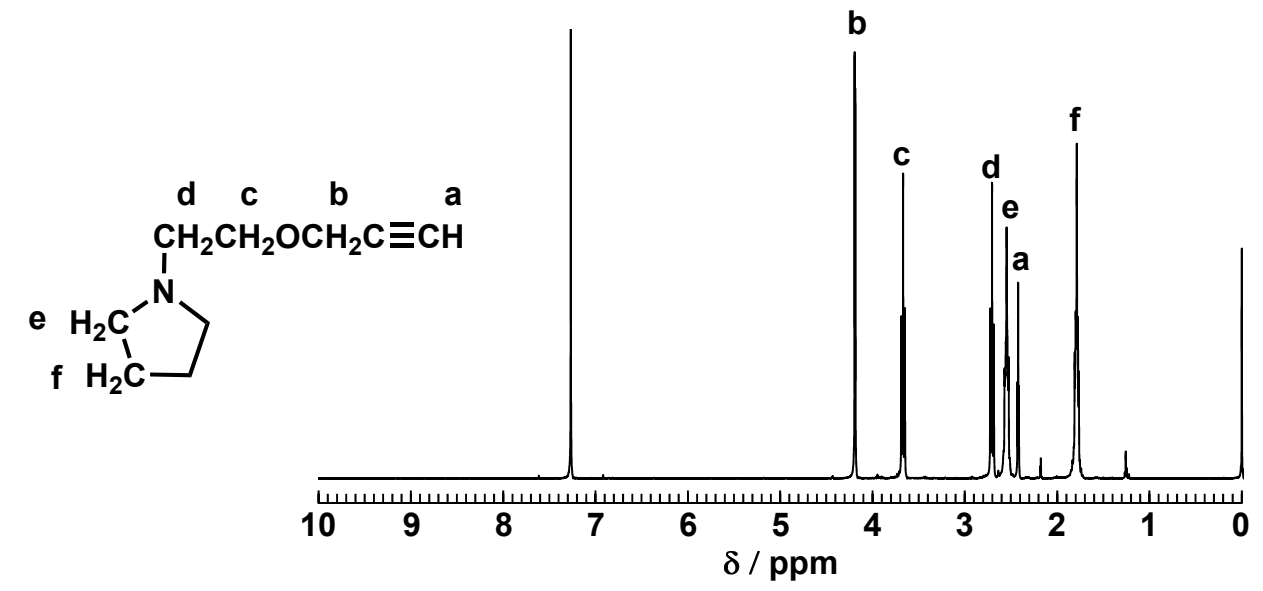

Figure S1: A $300 \mathrm{MHz}{ }^{1} \mathrm{H}-\mathrm{NMR}$ spectrum of 1-(2-(2-Propyn-1-yloxy)ethyl)pyrrolidine $\left(\mathrm{CDCl}_{3}\right)$. 


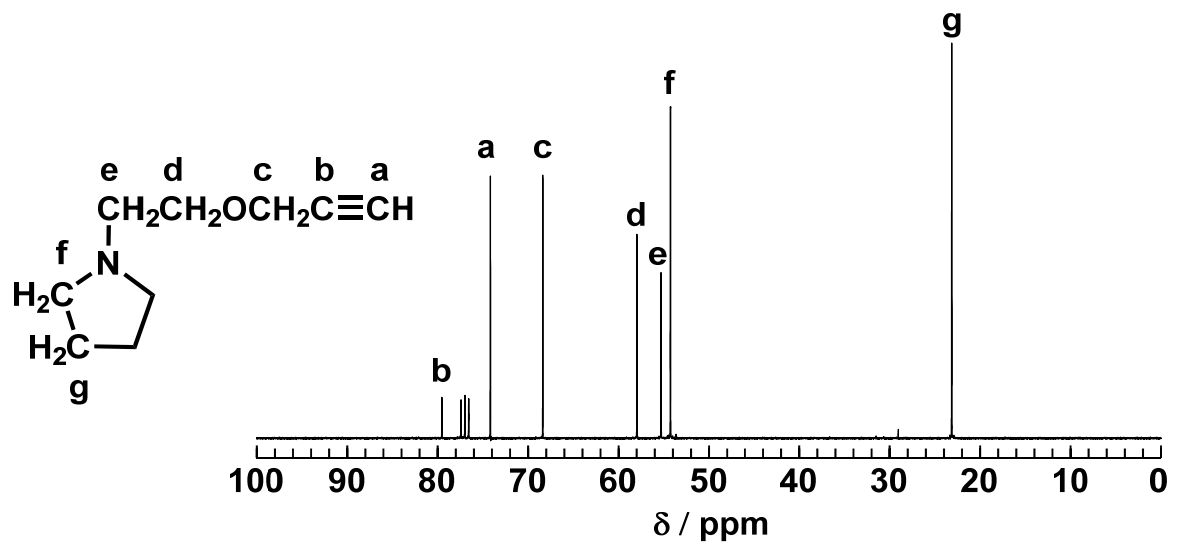

Figure S2: A $75 \mathrm{MHz}{ }^{13} \mathrm{C}-\mathrm{NMR}$ spectrum of 1-(2-(2-Propyn-1-yloxy)ethyl)pyrrolidine $\left(\mathrm{CDCl}_{3}\right)$. 


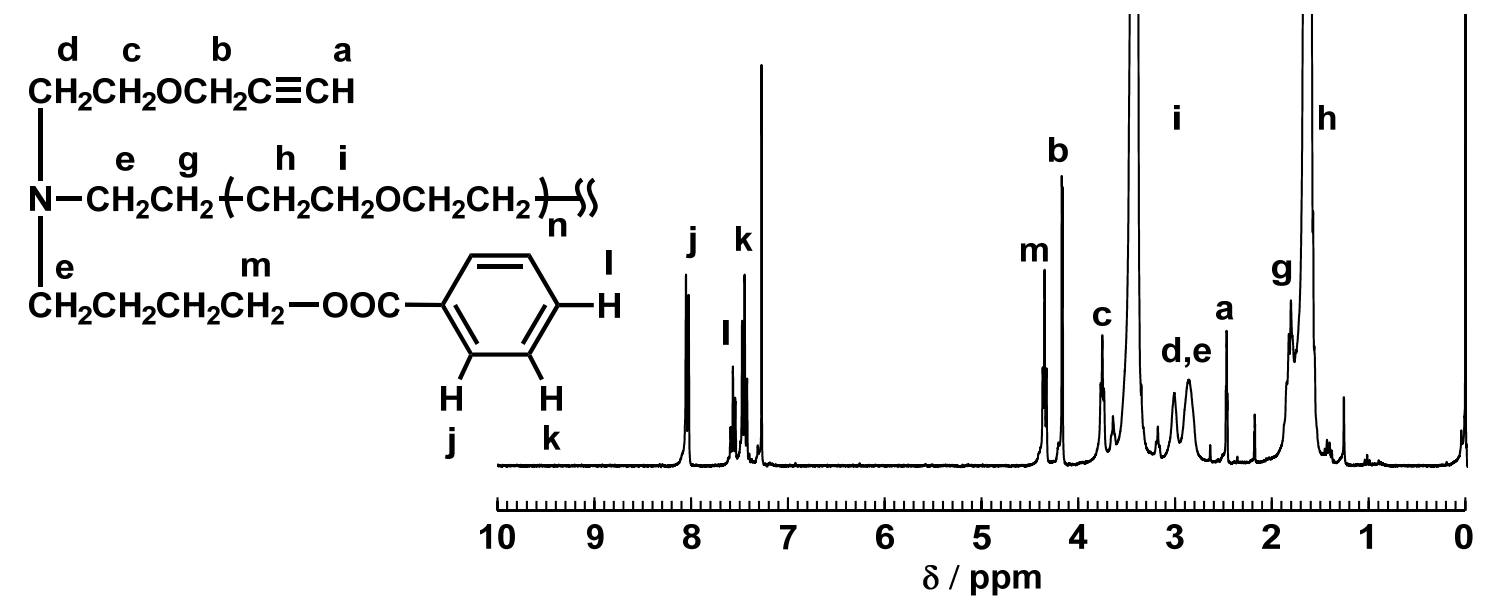

Figure S3: A $300 \mathrm{MHz}{ }^{1} \mathrm{H}-\mathrm{NMR}$ spectrum of the covalent conversion product from poly(THF) having an $N$-dialkylpyrrolidinium and an ethynyl end groups, $\mathbf{1}\left(\mathrm{CDCl}_{3}\right)$. 


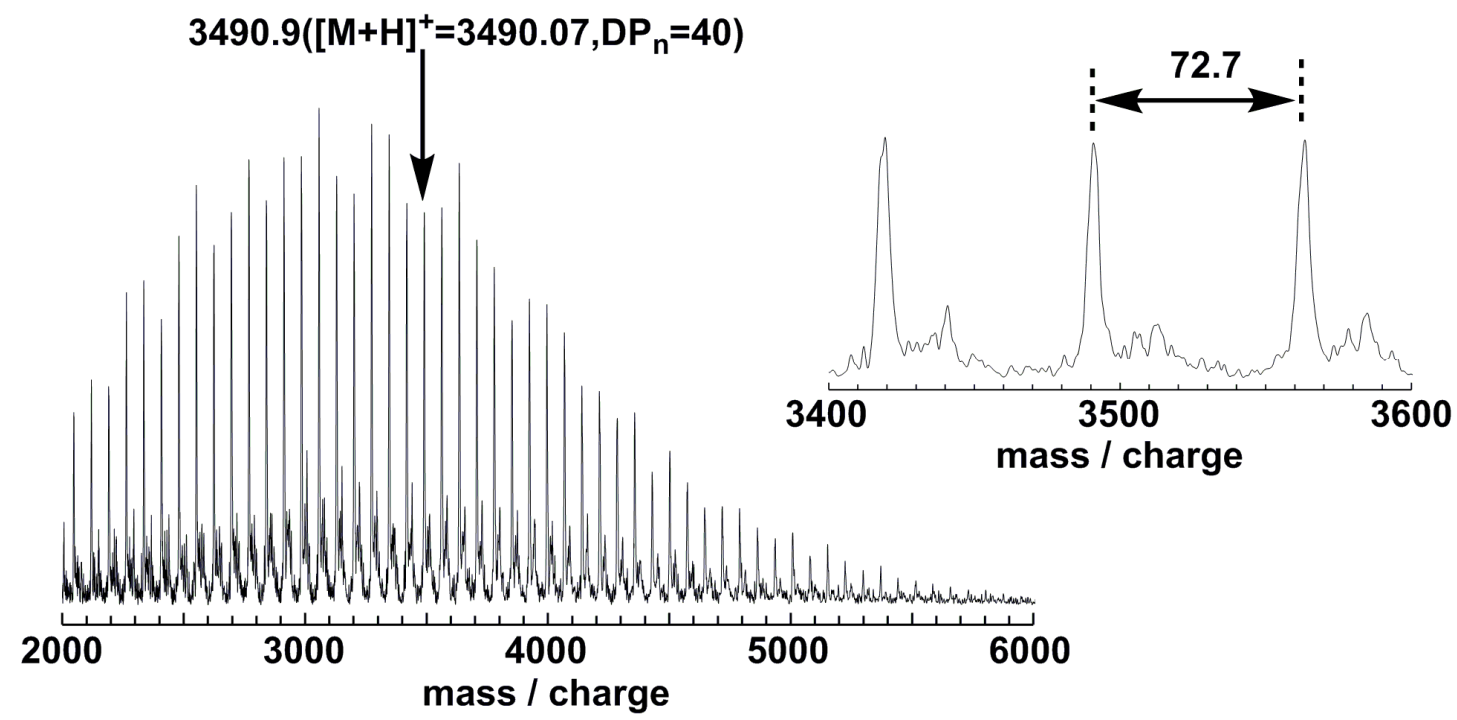

Figure S4: A MALDI-TOF MS spectrum of the covalent conversion product from poly(THF)

having an $\mathrm{N}$-dialkylpyrrolidinium and an ethynyl end groups, 1 (Linear mode, matrix: dithranol with sodium trifluoroacetate. $\mathrm{DP}_{\mathrm{n}}$ denotes the number of monomer units in the product.) 

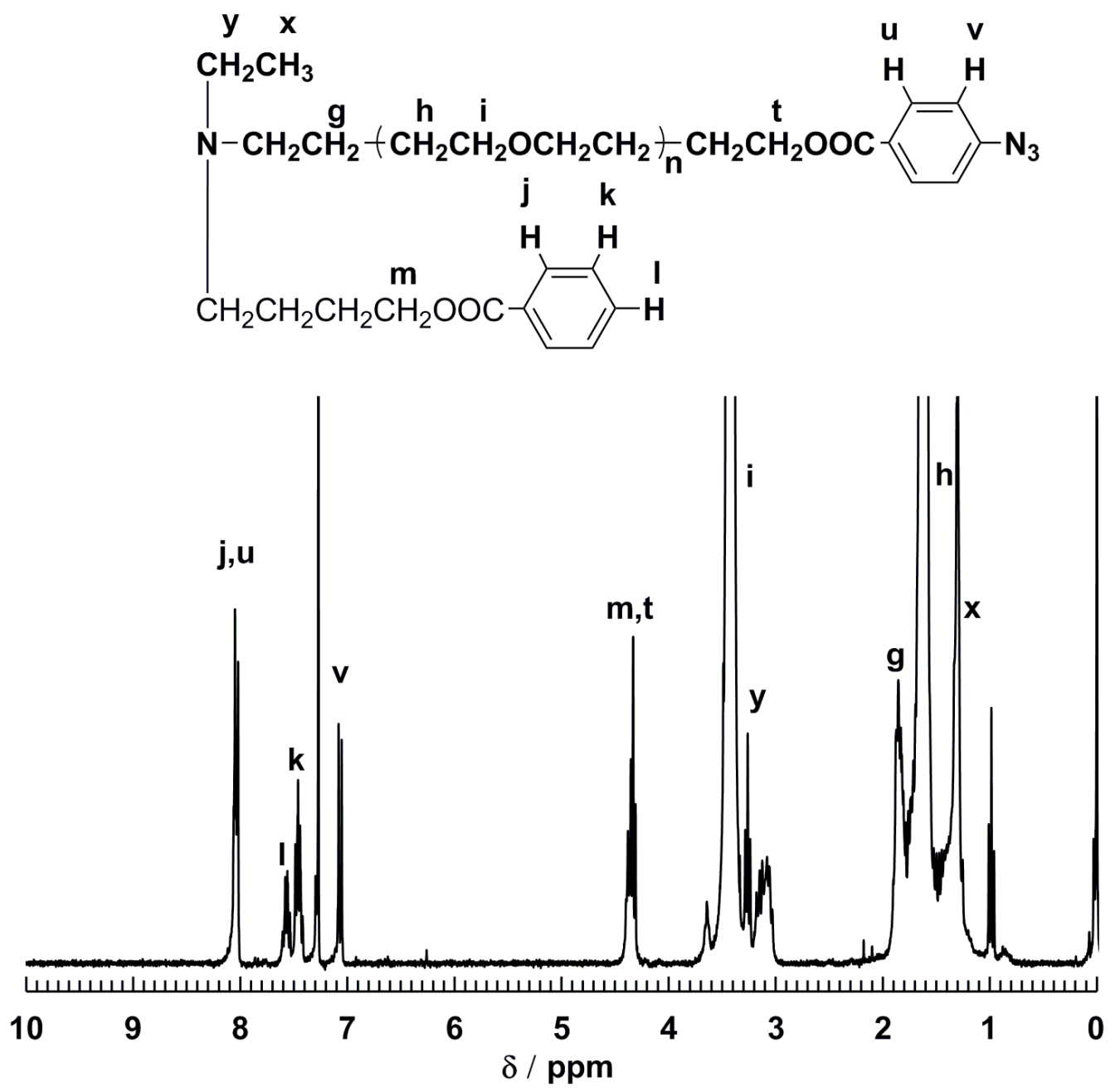

Figure S5: A $300 \mathrm{MHz}{ }^{1} \mathrm{H}-\mathrm{NMR}$ spectrum of the covalent conversion product from poly(THF) having an azidobenzoyl and an $N$-ethylpyrrolidinium end groups, $\mathbf{2 a}\left(\mathrm{CDCl}_{3}\right)$. 


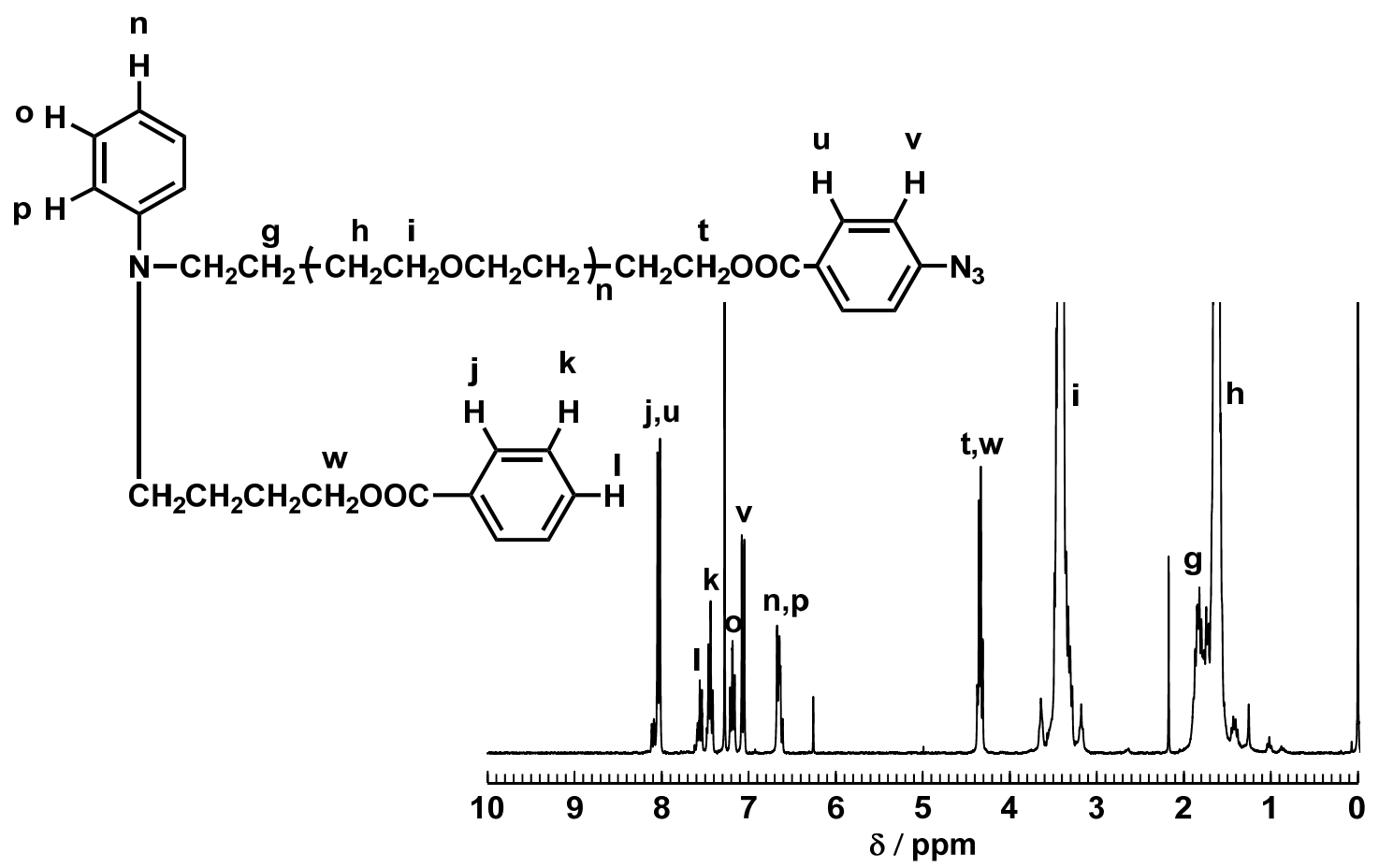

Figure S6: A $300 \mathrm{MHz}{ }^{1} \mathrm{H}-\mathrm{NMR}$ spectrum of the covalent conversion product from poly(THF)

having an azidobenzoyl and an $N$-phenylpyrrolidinium end groups, $\mathbf{2 b}\left(\mathrm{CDCl}_{3}\right)$. 


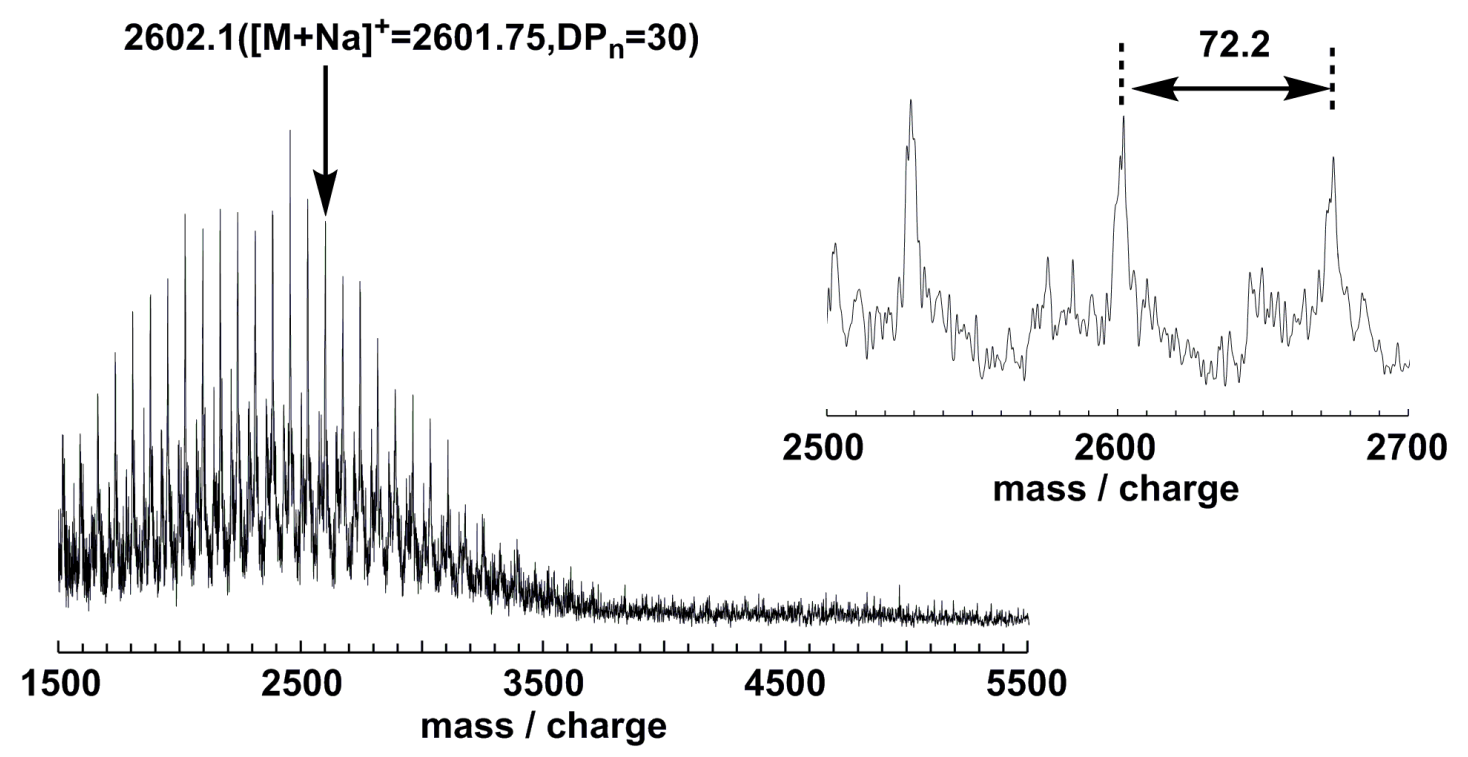

Figure S7: A MALDI-TOF MS spectrum of the covalent conversion product from poly(THF) having an azidobenzoyl and an $N$-ethylpyrrolidinium end groups, 2a (Linear mode, matrix: dithranol with sodium trifluoroacetate. $\mathrm{DP}_{\mathrm{n}}$ denotes the number of monomer units in the product.) 


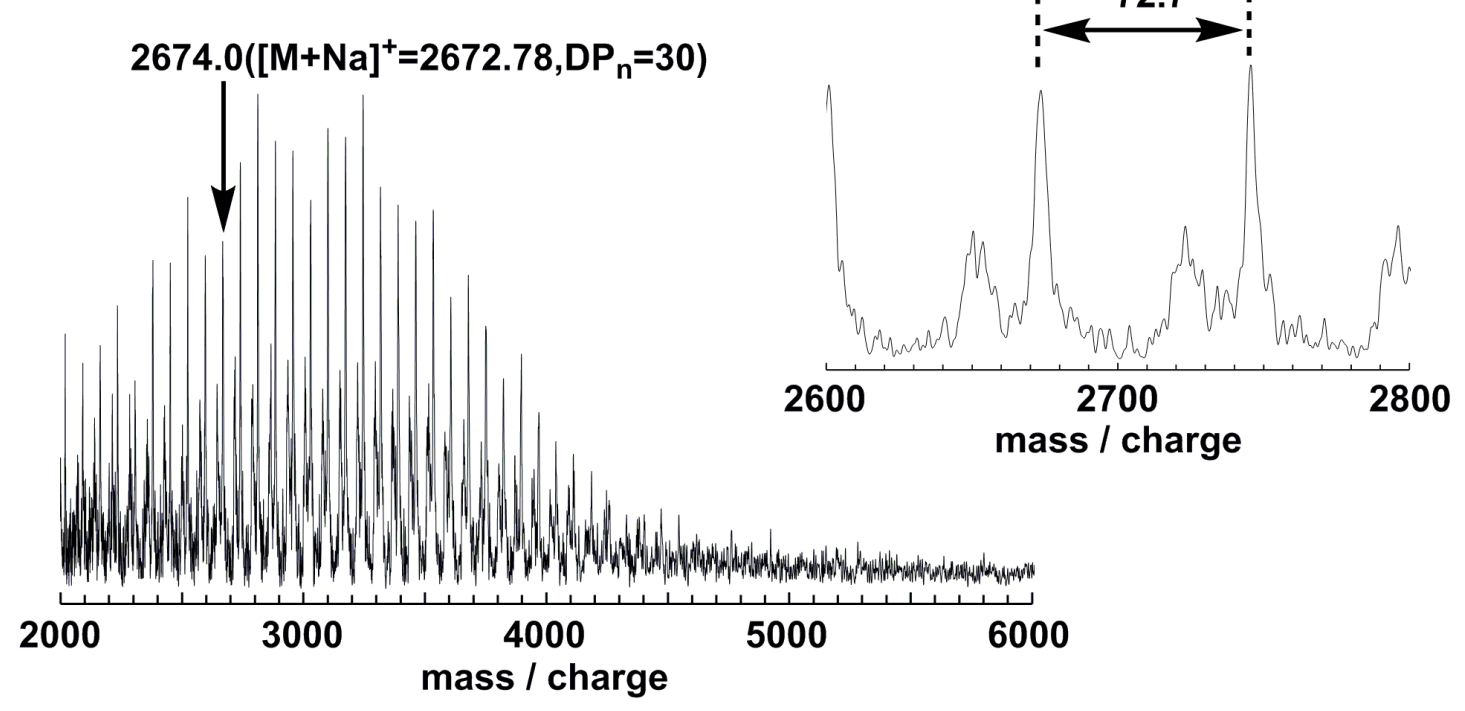

Figure S8: A MALDI-TOF MS spectrum of the covalent conversion product from poly(THF)

having an azidobenzoyl and an $N$-phenylpyrrolidinium end groups, $2 \mathbf{b}$ (Linear mode, matrix:

dithranol with sodium trifluoroacetate. $\mathrm{DP}_{\mathrm{n}}$ denotes the number of monomer units in the product.) 


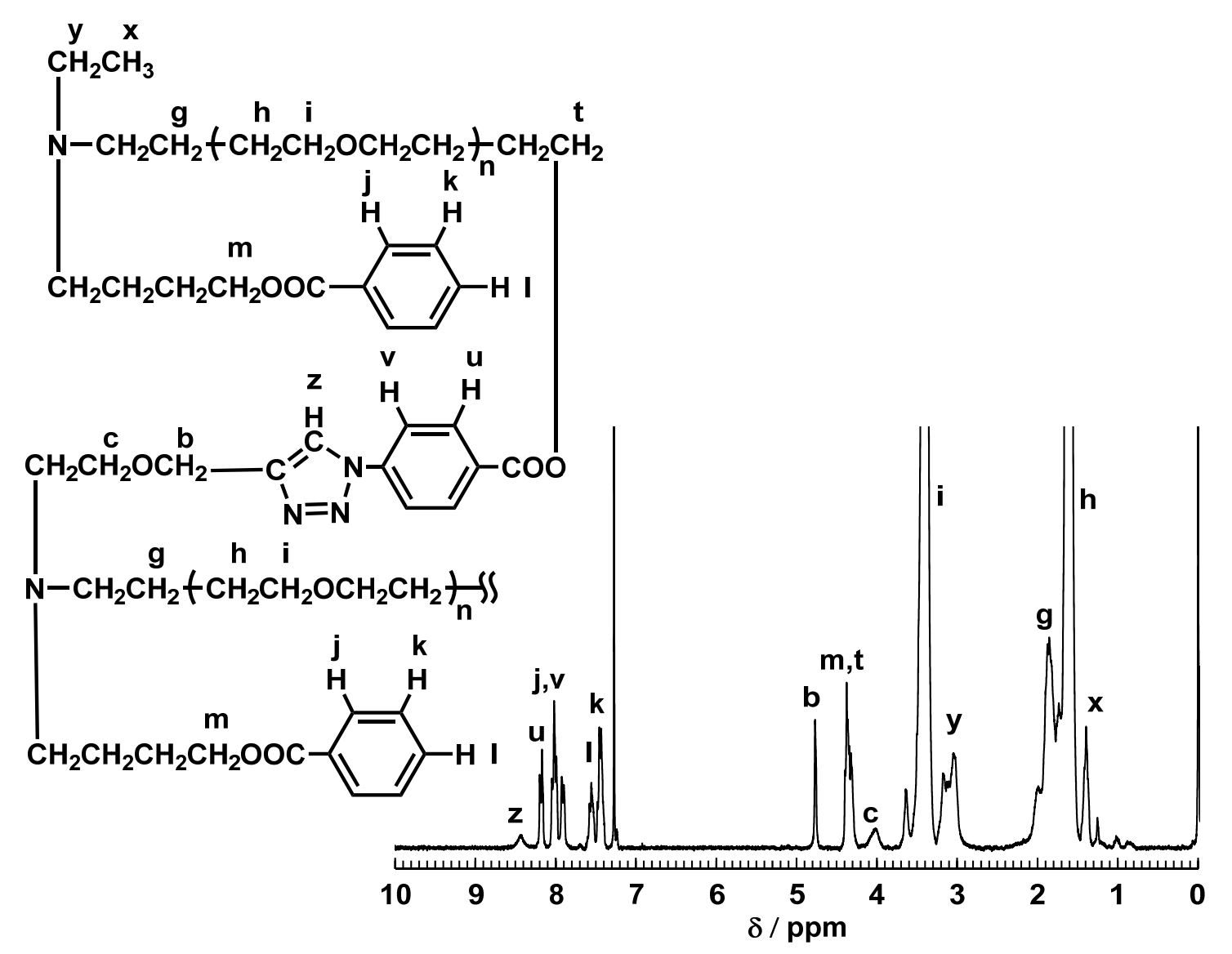

Figure S9: A $300 \mathrm{MHz}{ }^{1} \mathrm{H}-\mathrm{NMR}$ spectrum of the covalent conversion product from a tetrafunctional telechelic poly(THF) (Ia) isolated by the SEC preparative fractionation. $\left(\mathrm{CDCl}_{3}\right)$. 


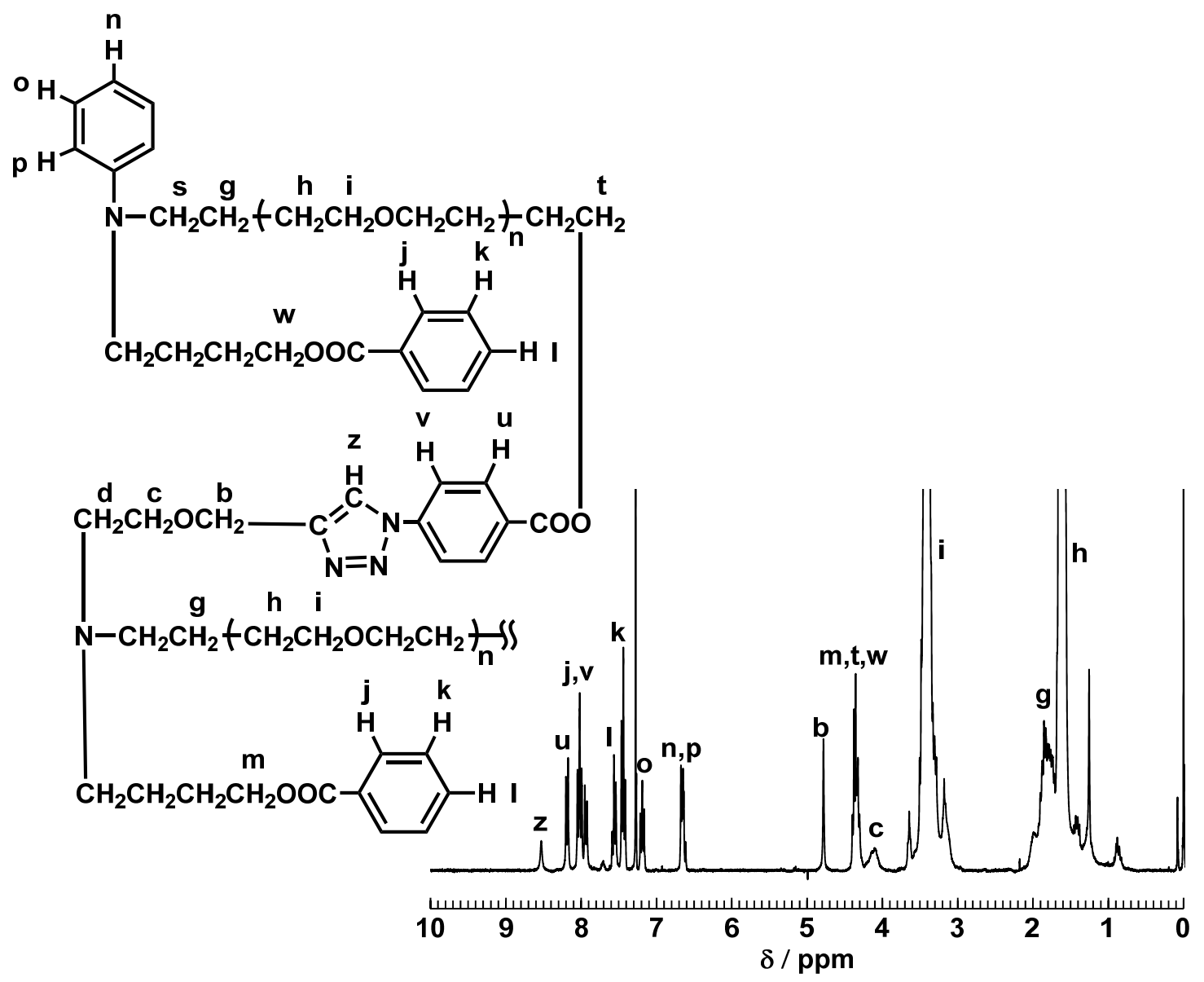

Figure S10: A $300 \mathrm{MHz}{ }^{1} \mathrm{H}-\mathrm{NMR}$ spectrum of the covalent conversion product from a tetrafunctional telechelic poly(THF) (Ib) isolated by the SEC preparative fractionation. $\left(\mathrm{CDCl}_{3}\right)$. 